\title{
The Relationship between Fluid Flow, Structures, and Depositional Architecture in Sedimentary Rocks: An Example- Based Overview
}

\author{
Vilde Dimmen (iD, Atle Rotevatn, and Casey W. Nixon \\ Department of Earth Science, University of Bergen, PO Box 7800, 5020 Bergen, Norway \\ Correspondence should be addressed to Vilde Dimmen; vilde.dimmen@uib.no
}

Received 12 August 2019; Revised 16 March 2020; Accepted 15 June 2020; Published 14 July 2020

Academic Editor: Rudy Swennen

Copyright (C) 2020 Vilde Dimmen et al. This is an open access article distributed under the Creative Commons Attribution License, which permits unrestricted use, distribution, and reproduction in any medium, provided the original work is properly cited.

\begin{abstract}
Fluid flow in the subsurface is fundamental in a variety of geological processes including volcanism, metamorphism, and mineral dissolution and precipitation. It is also of economic and societal significance given its relevance, for example, within groundwater and contaminant transport, hydrocarbon migration, and precipitation of ore-forming minerals. In this example-based overview, we use the distribution of iron oxide precipitates as a proxy for palaeofluid flow to investigate the relationship between fluid flow, geological structures, and depositional architecture in sedimentary rocks. We analyse and discuss a number of outcrop examples from sandstones and carbonate rocks in New Zealand, Malta, and Utah (USA), showing controls on fluid flow ranging from simple geological heterogeneities to more complex networks of structures. Based on our observations and review of a wide range of the published literature, we conclude that flow within structures and networks is primarily controlled by structure type (e.g., joint and deformation band), geometry (e.g., length and orientation), connectivity (i.e., number of connections in a network), kinematics (e.g., dilation and compaction), and interactions (e.g., relays and intersections) within the network. Additionally, host rock properties and depositional architecture represent important controls on flow and may interfere to create hybrid networks, which are networks of combined structural and stratal conduits for flow.
\end{abstract}

\section{Introduction}

It is well known that besides the intrinsic rock and fluid properties (i.e., porosity, permeability, fluid density, and viscosity), geological structures such as faults, fractures, and deformation bands may also strongly influence fluid flow (e.g., [1-4]). Understanding the interaction between fluid flow and geological structures is key for the comprehension of flow-and-reaction-related phenomena that tend to localize around faults and fractures (e.g., $[5,6])$, and hence fundamental for a variety of geological processes such as volcanism and metamorphism, as well as mineral dissolution and precipitation. Understanding subsurface fluid flow and reactions is also of economic and/or societal significance, given its relevance for the exploration and exploitation of ore mineral deposits, hydrocarbons, geothermal energy, contaminant transport, carbon storage, and groundwater aquifer management (e.g., [7-17]).
Different types of structures have different effects on flow. Open fractures, such as joints, may be highly conductive, whereas cemented fractures (veins) or deformation bands may be nonconductive or have very low permeability (e.g., [18-20]). Being able to identify and separate between different types of structures is therefore essential since they may have different effects on flow. Geological structures may act as conduits or barriers for fluid flow, or as a combination of the two. They may also have strongly anisotropic flow properties, e.g., acting as a barrier for cross-fault flow but as a conduit for fault-parallel flow (see [21-25]). It is common that flow properties of faults and fractures are transient and/or cyclic in nature, as faults and fractures vary between being open and closed for fluid flow through alternating fracturing, cementation/sealing, and refracturing (the so-called crackseal behaviour; [26-30]). Numerous studies have offered insight into how single structures, or pairs of interacting faults and their damage zones, may affect flow $[13,31,32]$. 
However, faults and fractures commonly occur in networks [33-35]. The relationship between fault and fracture network properties (topology, connectivity) on one hand, and fluid flow in rocks on the other, is still poorly constrained (e.g., [36]). Furthermore, it is well recognized that depositional architecture may strongly affect flow (e.g., [37]), yet there are few studies that address the interaction of depositional architecture and geological structures and their influence on fluid flow in and around fracture networks (e.g., [38]).

Motivated by the above, the main aim of this work is to give an overview, exemplify, and investigate both the depositional, architectural, and structural controls on fluid-rock interactive phenomena. To do this, we examine the spatial relationship between faults and fractures, fracture network topology, depositional architecture, and the distribution of Liesegang-type reaction-diffusion systems (Liesegang bands, e.g., [39]) and iron oxide deposits (collectively referred to herein as iron oxide precipitates (IOPs)).

In a recent study [40], we investigated the role of fracture network connectivity in controlling localized calcite cementation along small-scale faults and damage zones in limestone. Here, we investigate a fuller range of controls on flow as we discuss how fluid flow is affected by (i) host rock properties and depositional architecture and (ii) geological structures and structure networks, as well as their anisotropy, geometry, connectivity, kinematics, and mutual interaction. Finally, we look at the effect of hybrid networks of stratal and structural conduits. To do this, we study a variety of geological structures, both fractures, joints, and deformation bands, from New Zealand, Malta, and Utah (Figure 1), where IOPs represent a record of paleofluid flow in sandstones and limestones. Given the recent advances in fracture network analysis (e.g., [35, 41-44]), our overview of geologic controls on fluid flow, that also incorporates and quantifies the role of network properties on flow, is pertinent.

\section{Terminology}

We follow the structural terminology defined in Peacock et al. [45], but for clarification, we additionally provide a short explanation of some important terms used herein:

(1) Fractures: encompasses both joints and faults, as some of the studied fracture networks form parts of the damage zones of small-scale faults (displacements of $<1 \mathrm{~m}$ ), and comprises a combination of joints and faults. The joints and faults are hard to distinguish in an outcrop because of the centimeter-scale and lack of displacement markers

(2) Hybrid network: used herein to describe networks where geological structures such as joints or faults interact with more permeable layers or beds of a heterogenic sedimentary rock to increase the connectivity and create conduit networks

(3) Deformation bands: described as tabular, millimeterwide zones of localized but nondiscrete and distributed shear and/or compaction, and are typically low-permeable structures (generally 2-3, but occa- sionally up to 6 orders of magnitude lower permeability than host rock) that adversely affect flow properties [2, 46-51]

(4) Iron oxide precipitates (IOPs): used herein as a term to cover both Liesegang-type reaction-diffusion systems (Liesegang bands, e.g., [39]) and other iron oxide deposits (e.g., [20,52]). IOPs are a common by-product of fluid flow in rocks such as sandstone, limestone, and mudstone. Where IOPs occur preferentially in association with depositional heterogeneities (e.g., specific facies, strata, or bounding surfaces) and/or structural heterogeneities (e.g., faults and/or other types of fractures) in rocks, they may be used to infer the history of paleofluid flow and reconstruct how such heterogeneities acted to control flow $[16,39,52-55]$

\section{Geological Framework of the Study Sites}

New data presented herein are collected from various sites in New Zealand, Malta, and Utah. We combine qualitative field photographs of examples of simple structures like single fractures and deformation bands from New Zealand and Utah, with a more quantitative study of more complex fracture networks mainly from Malta but also from New Zealand.

3.1. Tongaporutu, Taranaki Basin, New Zealand. Present-day New Zealand is an active plate boundary that accommodates oblique convergence of the Australian and Pacific plates [56, 57]. Deformation band examples presented herein are from coastal exposures of faulted deep-water turbidites of the Upper Miocene Mount Messenger Formation in the Taranaki Basin on the West Coast of New Zealand's North Island (Figure 1(a)) [58-60]. The Taranaki Basin, exposed onshore along the Taranaki coastline, initially formed in Late Cretaceous times as a result of extension related to Gondwanan continental breakup and opening of the Tasman Sea (e.g., $[61,62])$. The basin has since seen a complex history, ranging from initial rift and passive margin phases, oblique reactivation, and overprint by convergent and extensional tectonics in Neogene times (e.g., $[59,63])$. Deformation bands in the Mount Messenger Formation have previously been described by Childs et al. [64] and Nicol et al. [65]; included in this study are examples of cataclastic shear bands in the cliffs along the Taranaki coast.

3.2. Hokianga, Northland Allochthon, New Zealand. The second study area in New Zealand is located on the southern shores of Hokianga in Northland (Figure 1(a)). Here, the Late Cretaceous Punakitere Sandstone [66-68] consists of massive to well-bedded sandstones with occasional conglomerate horizons, and sits within the Northland Allochthon [69, 70], the low-angle emplacement that occurred at the Oligocene-Miocene boundary [71]. The Punakitere Sandstone in Hokianga is affected by small-scale fracture networks, oriented NNE-SSW and NE-SW with associated IOPs. 


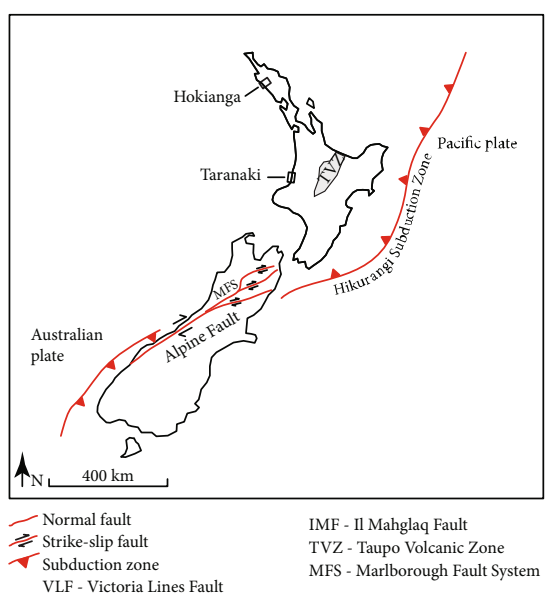

(a) New Zealand

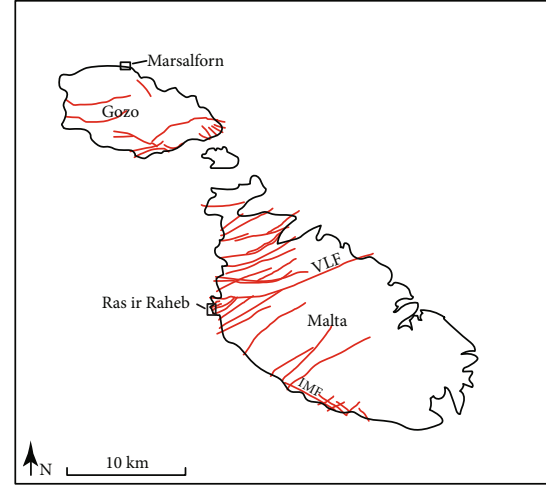

(b) The Maltese Islands

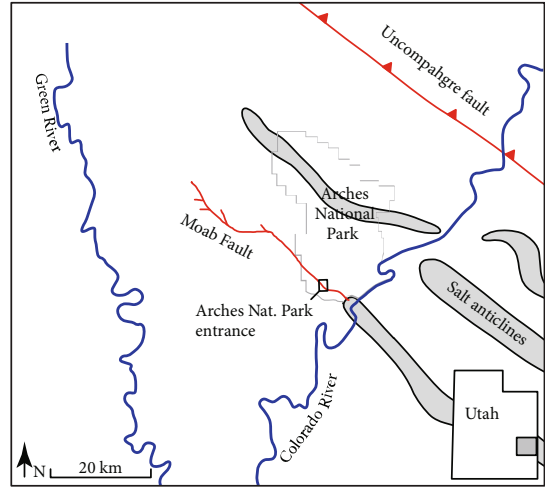

(c) Arches National Park

Figure 1: (a) Overview map of New Zealand, showing the field areas at Hokianga and the Taranaki coast on the North Island (after Sporli and Rowland, 2007). (b) Overview map of the Maltese Islands, showing the location of the field areas at Ras ir Raheb and Marsalforn (after [20, 79, 80]). (c) Overview map of the area of Arches National Park in SW Utah, USA, showing the field location by the entrance of Arches National Park (after Doelling, 1985; [53]).

3.3. Ras ir Raheb, Malta. The Maltese archipelago, consisting of the islands of Malta, Gozo, and Comino (Figure 1(b)), is situated on the north-eastern shoulder of the ESE-WNWtrending Pantelleria rift system [72], which formed as a response to back-arc extension related to ApennineMaghrebian subduction in Late Miocene-Early Pliocene times [73-76]. The back-arc extension also led to the formation of ENE-WSW-trending horsts and grabens, which dominate the Maltese structural framework (e.g., [74, 77, $78]$ ). The localities studied at Ras ir Raheb on the west coast of Malta, are situated approximately $1 \mathrm{~km}$ into the footwall of the Victoria Lines Fault (VLF) (Figure 1(b); [40, 78, 79]), which is a normal fault with a maximum displacement of c. $90 \mathrm{~m}$ [80]. The fault and fracture networks (displacement $<1 \mathrm{~m}$ ) examined here may be considered to be subsidiary faults in the damage zone of the Victoria Lines Fault $[40,81]$. The host rocks are Miocene-age, syn-rift, fine-grained foraminiferal limestones of the Middle Globigerina Limestone Member [74, 80].

3.4. Marsalforn, Gozo. Like the main island of Malta, Gozo is also characterized by ENE-WSW striking normal faults. However, the north-western part of the island stands out, as regional extensional strain related to the Pantelleria rifting event is expressed here as arrays of strike-slip faults [82]. The faults at the studied locality at Marsalforn (Figure 1(b)) occur in the Lower Globigerina Limestone Member, which outcrops as a yellow to orange, massive wackestone, packed with foraminifera and bivalves [80].

3.5. Arches National Park, Utah, USA. The last study areas are located close to the entrance of Arches National Park in SE Utah, USA (Figure 1(c)). Examples from here include deformation band clusters in the hanging wall of the Moab Fault and an anisotropic fracture network studied in a limestone bed in the footwall of the fault, just $5-15 \mathrm{~m}$ from the fault plane $[18,83,84]$. The deformation bands are found in the aeolian Entrada sandstone, which forms part of the latest Triassic to
Early Jurassic San Rafael Group [85, 86]. It consists of aeolian dunes and interdunes deposited in a hot and arid coastal environment in Mid-Jurassic times [84, 86, 87].

\section{Data and Methods}

Fieldwork involved the acquisition of structural field data and digital imagery from hand-held cameras. IOPs, and the extent of these, were mapped from photographs and field sketches, and length-displacement profiles were recorded for fractures that exhibited evidence for shear displacement.

For analysis of the fracture network examples, highresolution photography was used to digitize the networks using the NetworkGT toolbox in ArcGIS [88]. This was done to quantify the node and branch topology of the studied networks $[44,89]$. The elements in the two-dimensional networks are divided into nodes and branches, where nodes are ends or intersection points of fractures, and branches are segments of a fracture trace, bound by a node at each end (Figure 2) [42, 44]. The degree of connectivity of the network can be determined by the proportion of different nodes and branches, as elaborated in Sanderson and Nixon [44]. From the digitized maps of the networks, we used the Kernel Density tool in the built in ArcToolbox in ArcGIS to extract contour maps of (i) fracture intensities, which represent the total branch length per square meter $\left(\mathrm{m} / \mathrm{m}^{2}\right)$, and (ii) the connecting node frequencies, to illustrate the frequency of connections per square meter $\left(N_{\mathrm{C}} / \mathrm{m}^{2}\right)$ [44]. These maps provide a good visualisation of the internal variations of the network complexity and connectivity.

\section{Examples of Fluid Flow Relationships with Structures and Networks: Field Observations and Characterization}

5.1. Depositional Architecture. We studied the relationship between depositional architecture and paleofluid flow at 


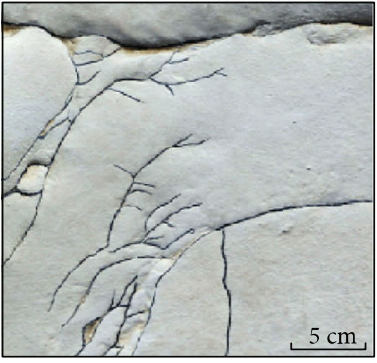

(a)

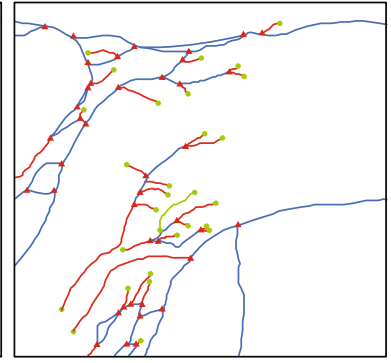

(b)

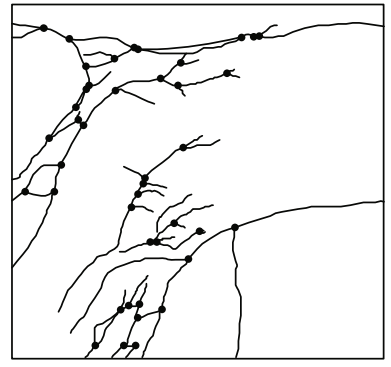

(c) (d)
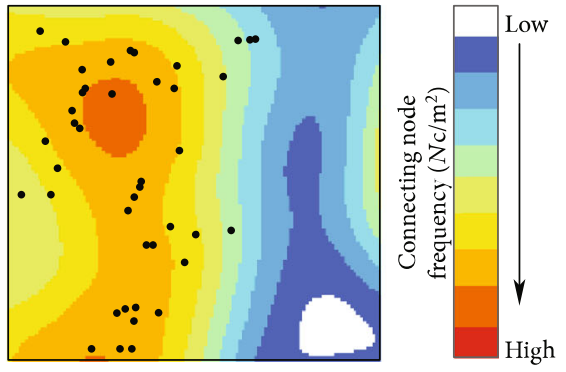

$\begin{array}{ll}\text { I-node } & \text { - I-I branch } \\ \text { - Y-node } & -\mathrm{I}-\mathrm{C} \text { branch } \\ \text { - X-node } & -\mathrm{C}-\mathrm{C} \text { branch } \\ \text { - Connecting nodes } & \end{array}$

Figure 2: (a) Example of a fracture network from the field at Ras ir Raheb, Malta. (b) Topological characterization of the example shown in (a), using topological nomenclature proposed by Sanderson and Nixon [44]. We differentiate between different types of nodes and branches. Nodes are classified as isolated nodes (I-nodes), abutting or splaying nodes (Y-nodes), or as crossing nodes (X-nodes). Branches are classified as isolated (I-I), partly connected (I-C), or fully connected (C-C). (c) Network showing only the connecting nodes. (d) Illustration of the connecting node frequency (connecting nodes $/ \mathrm{m}^{2}$ ) of the fracture network.

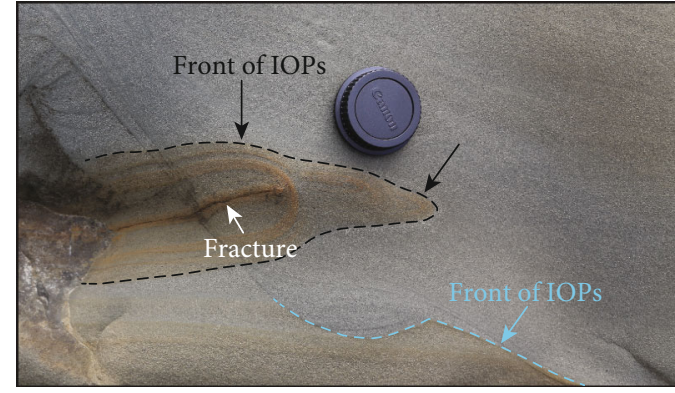

(a)

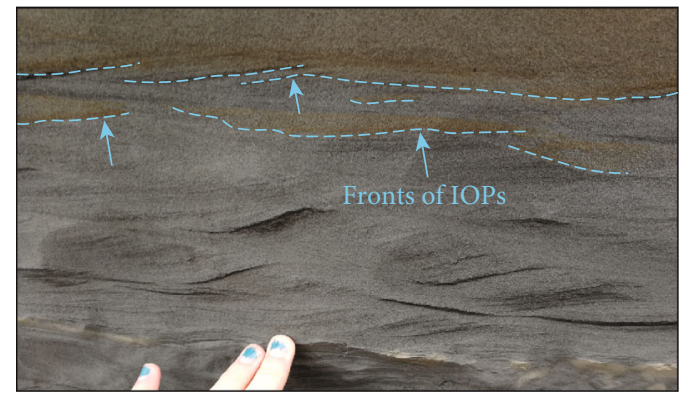

(b)

Figure 3: (a) Example of how a fracture (white arrow) can control the formation and extent of iron oxide precipitates (black, dashed line) and how depositional architecture (blue arrow) may control the flow of oxidizing fluids (blue, dashed line); Hokianga, New Zealand. (b) Another example of how depositional architecture, here in the form of crossbedding, can control the extent of iron oxide precipitates; Taranaki, New Zealand.

several locations around New Zealand's North Island, and two were chosen as examples herein. Figure 3(a) shows a photo from an outcrop along the Hokianga coast, where millimeter- to centimeter-scale depositional structures create heterogeneities in the otherwise homogenous Punakitere Sandstone. Parts of the rock have a brown-orange colour, due to IOPs, which stands out against the grey sandstone. An $\sim 15 \mathrm{~cm}$ long joint cuts through the depositional structures in the middle of the photograph. This joint is associated with a highly localized IOP envelope that tapers out ahead of the joint tip. This IOP envelope is also to some extent controlled by sedimentological heterogeneity, in that its upper boundary follows a sandstone crossbed. This illustrates how fluid flow may be influenced by both depositional heterogeneities and structural heterogeneities in one example. The second example, Figure 3(b), is showing centimeter-sized crossbedding in a cliff along the Taranaki coast. The muddy sandstone is mainly grey in colour, but some IOPs have stained parts of the rock, filling in the crossbeds in the uppermost part of the photo. Both of these exam- ples illustrate how depositional architecture can create spatial heterogeneities in porosity/permeability producing local flow paths through otherwise homogenous rocks.

5.2. Simple Geological Structures. Figure 4 shows examples of joints and their relationship to IOPs from Hokianga, North Island, New Zealand. The first example (Figure 4(a)) shows two subparallel joints-one through-going joint from left to right and another joint, $\sim 10 \mathrm{~cm}$ above, coming in from the left and terminating at a tip to the right. An envelope of IOPs encloses the joints, staining the surrounding sandstone brown-orange, and clearly deflects and narrows ahead of the terminating joint tip. This illustrates the fact that the spatial distribution of iron oxide deposits can be controlled by multiple (two) fractures: the envelope is widest where it is controlled by two main joints, and narrowest where it is only controlled by one. Another example from Hokianga shows a joint set comprising two right-stepping segments (Figure 4(b)). This joint set is associated with a brownorange iron oxide envelope, which closely trails the segmented 


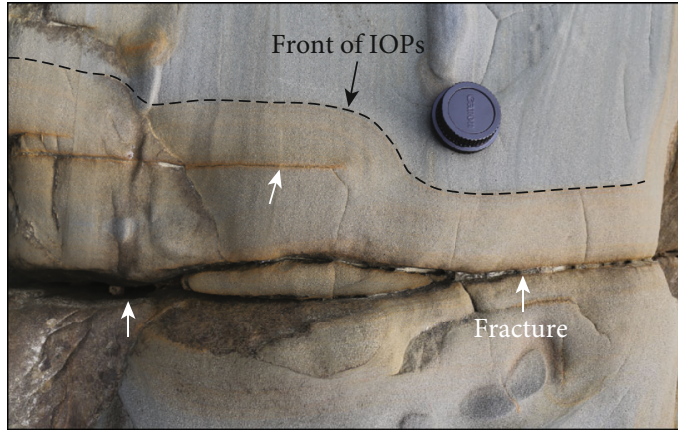

(a)

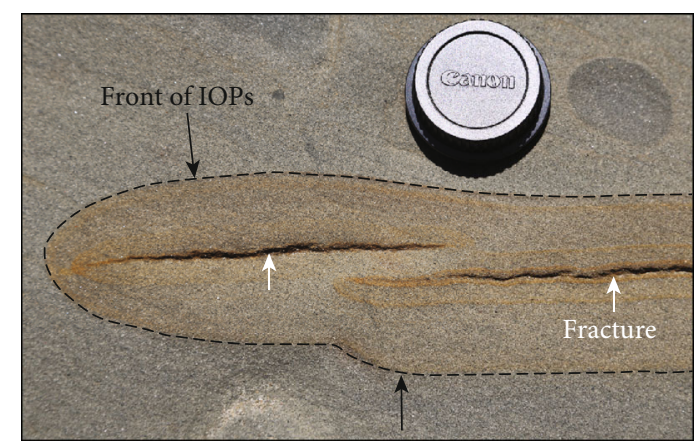

(b)

Figure 4: (a) Example of fracture tip interaction, where the front of the iron oxide precipitates (black, dashed line) curves out where the fracture tips overlap; Hokianga, New Zealand. (b) Example of how iron oxide precipitates respond to fracture-tip interaction: the front of the iron oxide precipitates (black, dashed line) narrows as the fractures (white arrows) tip out; Hokianga, New Zealand.

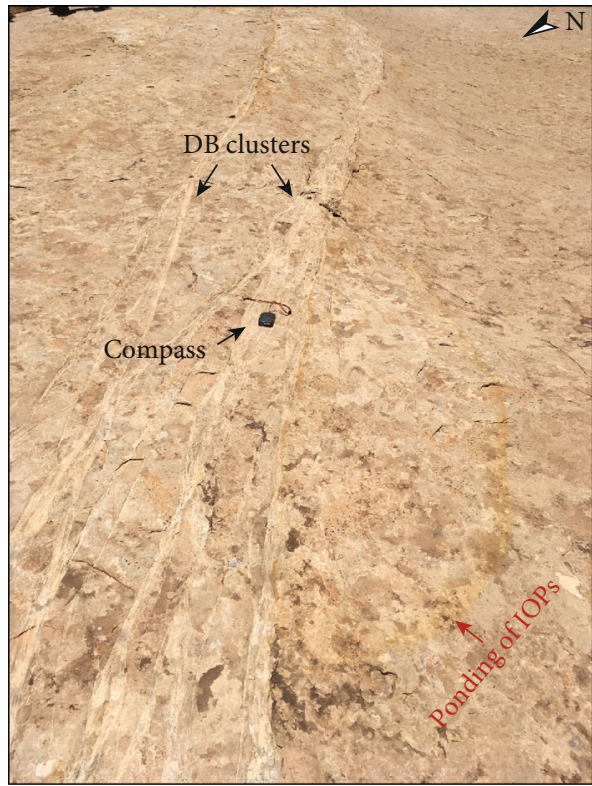

(a)

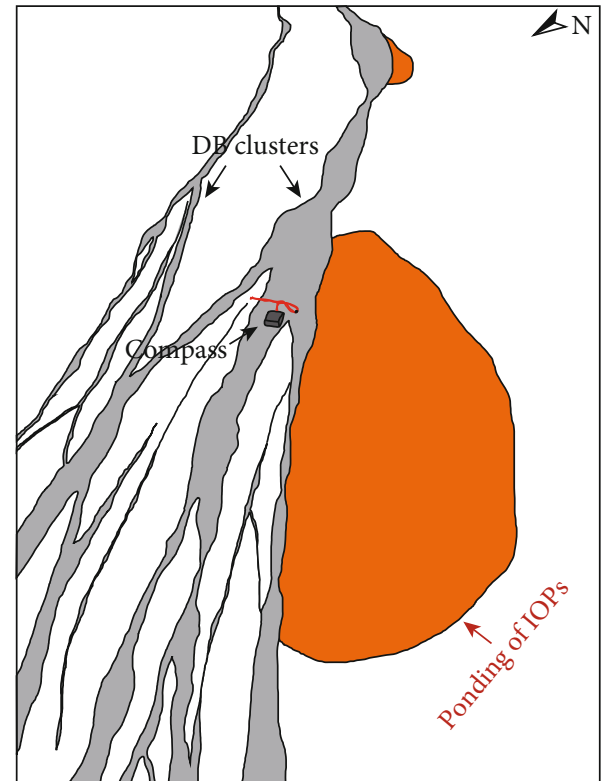

(b)

Figure 5: (a) Field photo and (b) sketch of deformation band cluster causing ponding of iron oxide precipitates (IOPs) found in Arches National Park, Utah, USA.

joint system. Where the joint system steps right-laterally, the envelope similarly makes a gentle right-lateral shift. Hence, the IOPs, and inferred paleofluid flow, are clearly affected by the joints, as the fronts of the IOPs follow the extent of the joints. These examples show how simple geological structures can act as conduits, controlling and localizing the distribution and flow of fluids.

Figure 5 presents an example of deformation bands formed within the Entrada sandstone in Utah. The locality shows a NW-SE-oriented cluster of deformation bands on a gently SW-sloping pavement. The cluster stretches tens of meters in length with a variable width of up to $\sim 1 \mathrm{~m}$. The front of IOPs are located on the pavement immediately down dip of the cluster, towards the SW, locally forming orangecoloured half circles in the sandstone. These represent ponding of fluids against the deformation band cluster which has acted as a barrier to fluid flow.
Examples of deformation bands were also documented in the cliffs along the Taranaki coast, New Zealand (Figure 6). In Figures 1(c) and 6(b), two oblique deformation bands cross each other with an intersection angle of approximately 60 degrees. One deformation band is visible as a distinct grey line crossing the photograph from left to right and appears to have no associated IOPs. Whereas the second deformation band has a clear association with IOPs, visible as a rusty orange line crossing the grey deformation band. An additional example in Figures 6(c) and $6(\mathrm{~d})$ shows a single deformation band crossed by a series of IOP fronts, which are clearly not affected by the deformation band. Even though these are all examples of deformation bands, they show very different relationships with fluids, i.e., some act as conduits localizing flow, some act as barriers, and others have little or no effect on the distribution of IOPs. 


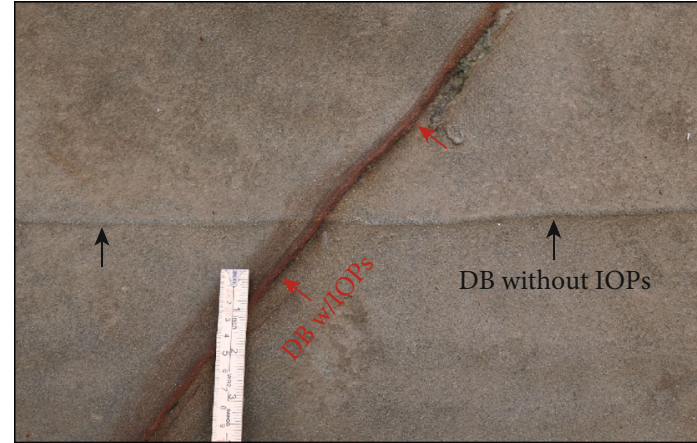

(a)

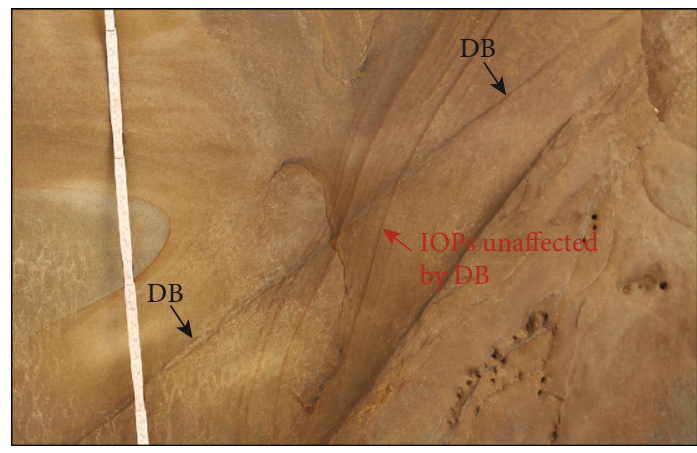

(c)

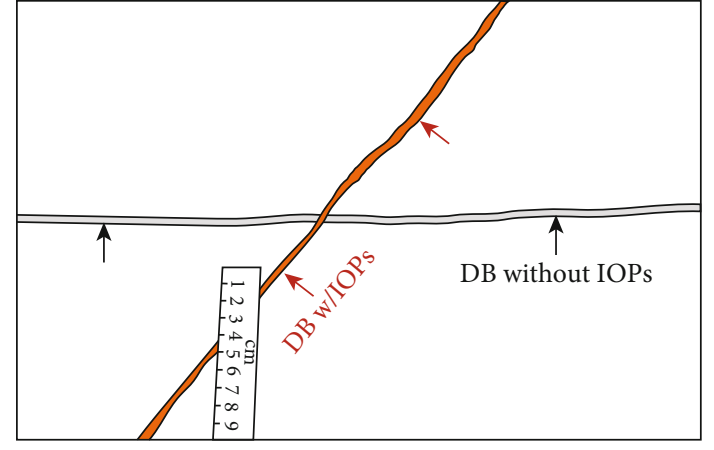

(b)

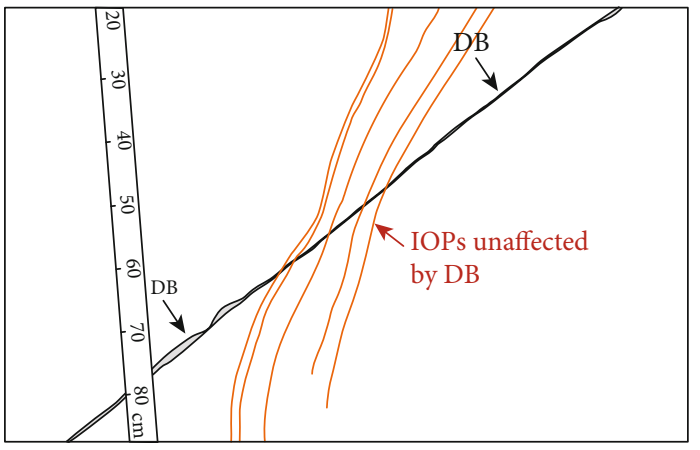

(d)

Figure 6: (a) Field photo and (b) sketch of a deformation band functioning as a capillary conduit controlling oxidation (red arrows) and a deformation band without any oxidation at all (black arrows: horizontal in picture, dipping away from perspective); Taranaki coast, New Zealand. (c) Field photo and (d) sketch of example where bands of iron oxide precipitates (pointed out by red arrow) clearly ignore a deformation band (black arrows); Taranaki coast, New Zealand.

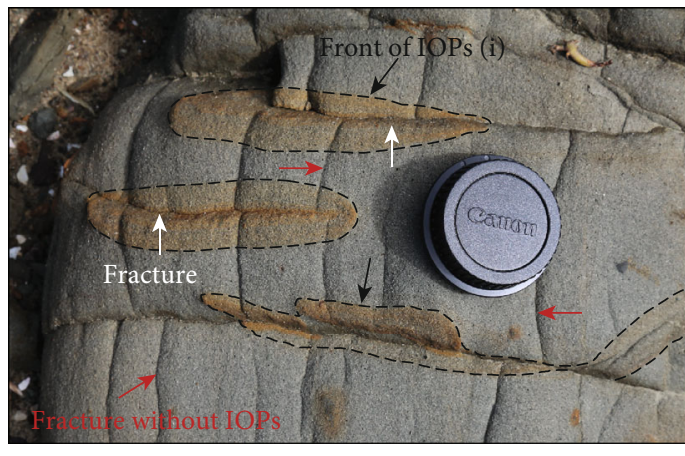

(a)

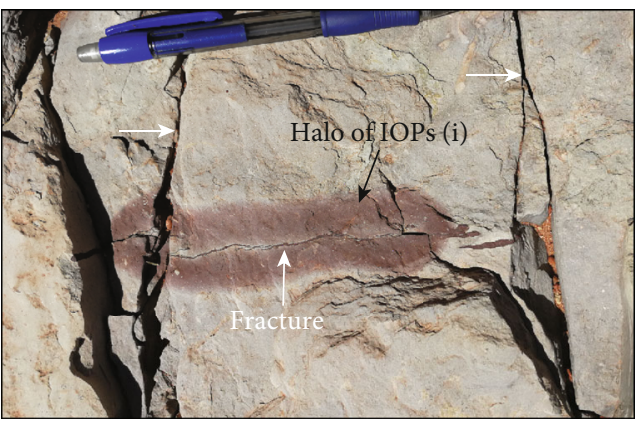

(b)

Figure 7: Not all fractures act as conduits for fluid flow, and hence iron oxide precipitates do not surround all fractures. Along-strike variability of the fractures may cause along-strike variability in the distribution of iron oxide precipitates. Examples from (a) Hokianga, New Zealand and (b) the footwall of the Moab Fault in Arches National Park. White arrows point to the areas of fractures associated with iron oxide precipitates, while the red arrows point towards some of the fractures which do not promote formation of iron oxide precipitates.

5.3. Simple Structural Networks. As previously mentioned, geological structures can interact and form networks. Within the Punakitere Sandstone at Hokianga, New Zealand, we documented a fracture network comprising two orthogonal joint sets; one systematic joint set (trending right to left; Figure $7(\mathrm{a})$ ) abutted by a set of cross-joints (trending top to bottom; Figure 7(a)). Elongated haloes of orange-coloured IOPs form around the systematic joint set whereas the cross-joints are unaffected by IOPs. A similar example is shown in Figure 7(b), which comprises two orthogonal frac- ture sets that mutually cross-cut and abut one another in a limestone bed, located in the footwall of the Moab Fault in Arches National Park, Utah. Again in this example, one fracture set is surrounded by a brown-red halo of IOPs (trending right to left; Figure 7(b)), whereas the orthogonal crosscutting fracture set (trending top to bottom; Figure 7(b)) has no association with IOPs. Both examples illustrate that not all structures within a network are conductive to flow, which is important as it will produce an anisotropy in the flow properties of a fractured rock mass. 


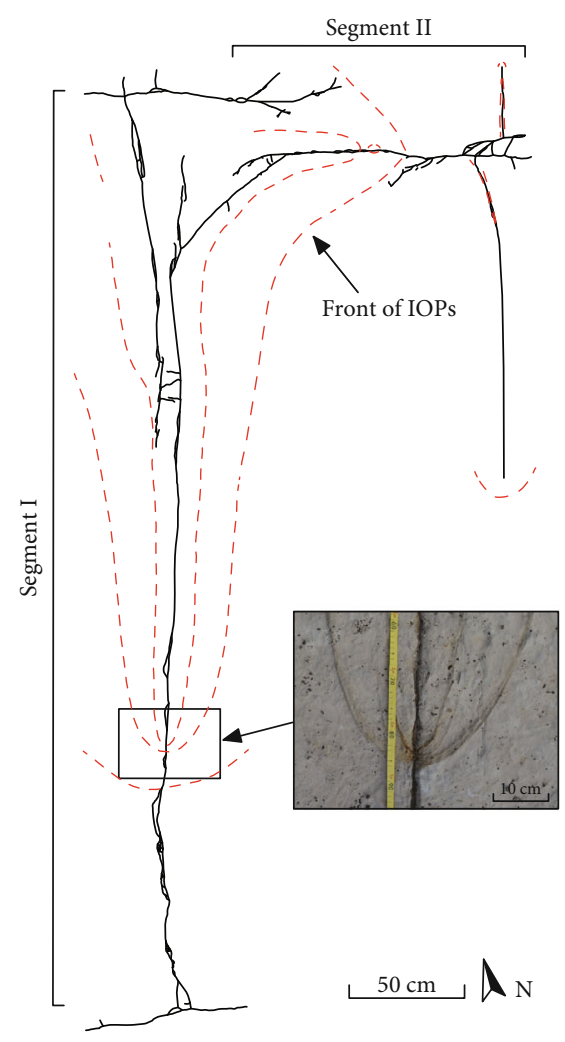

(a) Fracture network

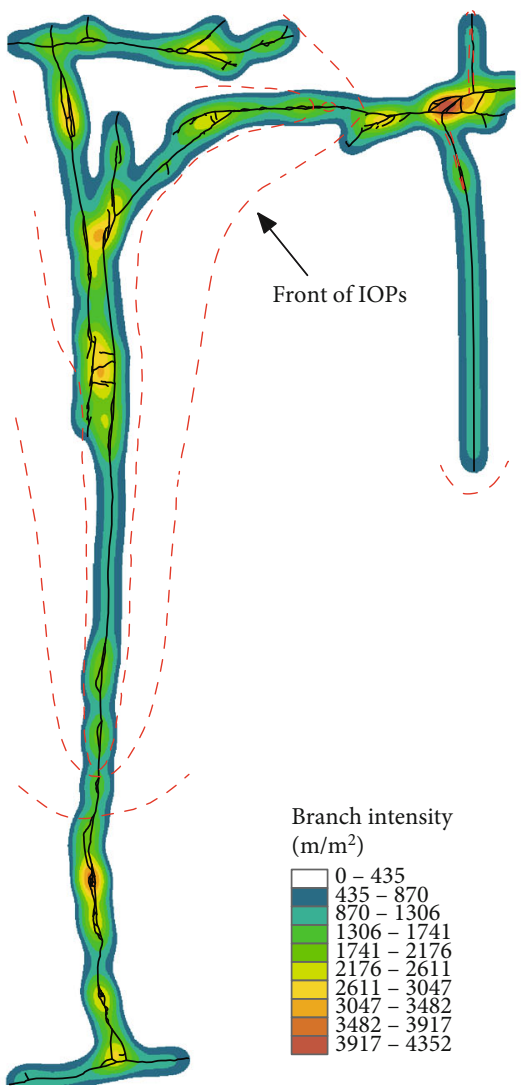

(b) Branch intensity

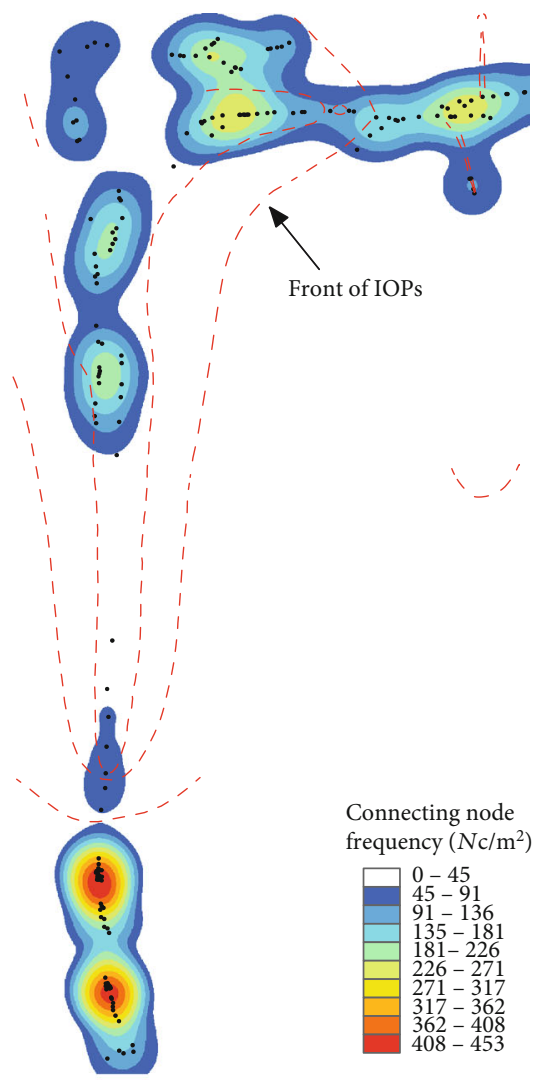

(c) Connecting node frequency

$\frown$ Branch

- Front of IOPs

- Connecting node

FIGURE 8: (a) Digitized map of the fracture network at Ras ir Raheb, Malta, with iron oxide precipitates shown as red dashed lines. A photo of a clear front of iron oxide precipitates is included. (b) The branch intensity map indicates higher density in complex zones. (c) Connecting node frequency map of the locality shows that zones with high branch intensity generally tend to coincide with high connecting node frequency.

5.4. Complex Structural Networks. The examples in Figure 7 are relatively simple fracture networks with two orthogonal sets. However, fractures often form more complex networks consisting of different fracture types as well as a range of fracture sizes and orientations. In the following examples (Figures 8, 9, 10 and 11), we explore more complex fracture networks and investigate the relationships between different fracture network attributes (e.g., fracture intensity, connectivity, and displacement) and the distribution of IOPs. These examples of more complex fracture networks are associated with a number of mesoscale fault systems formed in carbonate rocks located in Malta. The first example consists of two intersecting segments (I and II; Figure 8(a)), each comprised of several joints and minor normal faults with displacement of up to $\sim 2.5 \mathrm{~cm}$. The $\mathrm{N}$-S-oriented segment I comprises two smaller, hard-linked fault segments. The E-W-oriented segment II continues 2-3 meters towards the east, outside of the area covered by Figure 8, where it tips out and overlaps with another segment to form a relay ramp (see Figure 1(a) in the supplementary materials (available here)). Distinct, red
IOPs are widest around the intersection point of segments I and II. The intersection is also characterized by higher branch intensities and connecting node frequencies (Figures 8(b) and 8(c)). The strong IOP front tapers off to the south and east along segment I and segment II, respectively. Although some local, smaller maxima in branch intensity and node frequency are found further south and east along the main segments, outside the intersection, only weaker, discontinuous fronts are observed locally and often around fracture tips.

In Figure 9, we have an example of a normal fault system with an outcropping trace length of $\sim 22 \mathrm{~m}$ and a maximum displacement of $\sim 25 \mathrm{~cm}$ (see also Figure 2 in the supplementary materials). The fault system consists of a network of small faults and fractures that trend SE-NW and dip $\sim 60^{\circ}$ towards the SW. For ease of description, the system is divided into two distinct main segments (segments I and II; Figure 9(a)), which are linked through a more intensely fractured zone. Contour maps of fracture intensity and connecting node frequency are presented in Figures 9(b) and 9(c), 


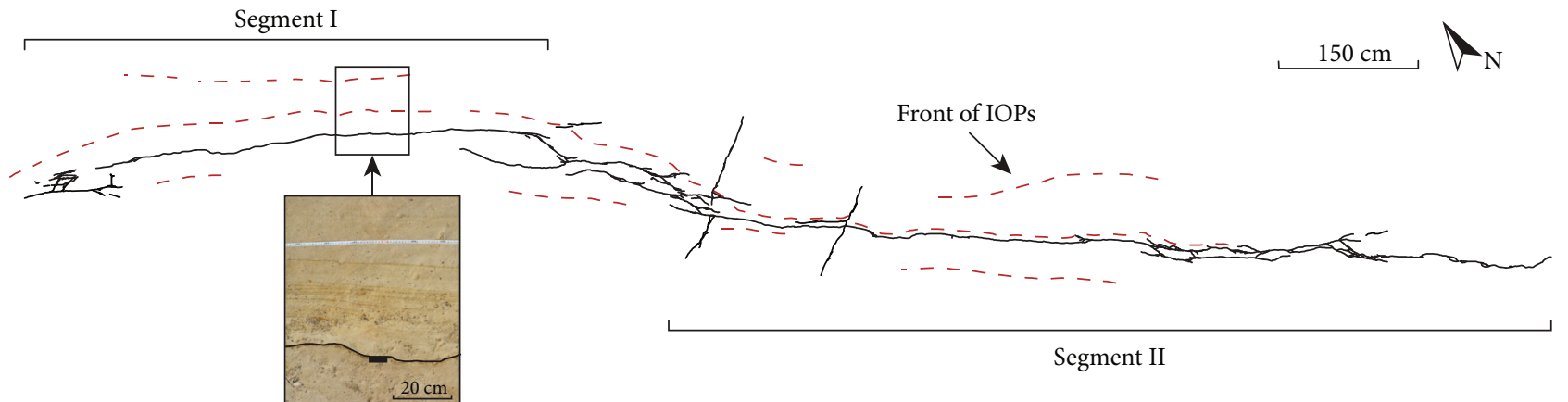

(a) Fracture network

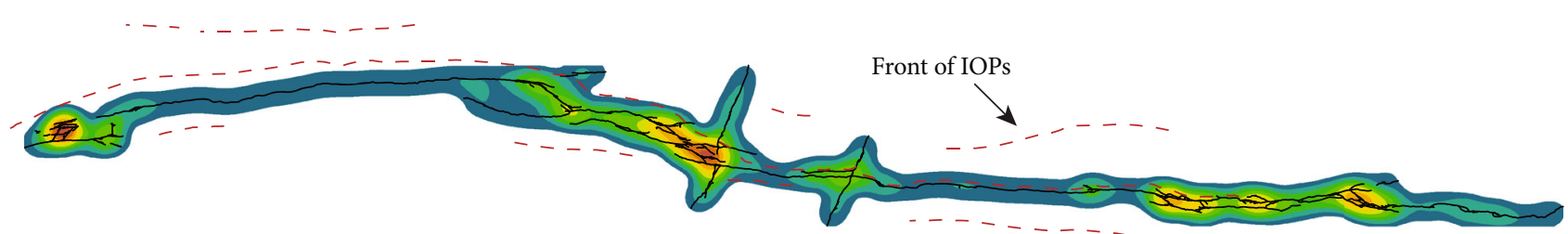

(b) Branch intensity

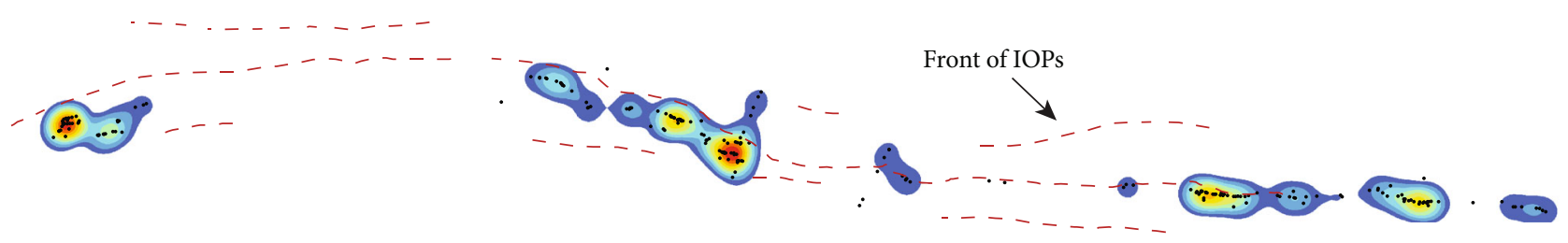

\begin{tabular}{|c|c|}
\hline $\begin{array}{l}\text { Connecting node } \\
\text { frequency }\left(\mathrm{Nc} / \mathrm{m}^{2}\right)\end{array}$ & $\begin{array}{l}\text { Branch intensity } \\
\left(\mathrm{m} / \mathrm{m}^{2}\right)\end{array}$ \\
\hline $0-8$ & $0-112$ \\
\hline $8-16$ & $112-223$ \\
\hline $16-24$ & $223-335$ \\
\hline $24-32$ & $335-446$ \\
\hline $32-40$ & $446-558$ \\
\hline $40-48$ & $558-669$ \\
\hline $48-56$ & $669-781$ \\
\hline $56-64$ & $781-892$ \\
\hline $64-72$ & $892-1004$ \\
\hline $72-80$ & $1004-1116$ \\
\hline
\end{tabular}

(c) Connecting node frequency

- Branch

- - - Fronts of IOPs

- Connecting node

Figure 9: (a) Digitized map of the fracture network at Ras ir Raheb, Malta, with iron oxide precipitates shown as red dashed lines. (b) The branch intensity map indicates higher density in the areas of segment linkage. (c) Map of the connecting node frequency, which also increases in the areas where fault segments link indicating higher connectivity in linkage areas.

respectively, generally showing that high connecting node frequencies correspond with areas of high fracture intensity. A series of profound red-stained IOP fronts, predominantly in the footwall of the fault system, form an envelope of $\sim 50 \mathrm{~cm}$ around the main fault segments (see inset in Figure 9(a)). Weaker, discontinuous fronts can be observed locally further away from the main segments, as well as a few, discontinuous fronts in the hanging wall (Figures 9(a)9(c) and Figure 2(b) in the supplementary materials). A widening of the IOP front can be observed at the linkage of the two fault segments. However, this is the only location where IOP width coincides with increases in fracture intensity and connecting node frequency. Instead, the width of the IOP fronts appear to reflect relative changes in displacement along strike of the fault system (Figure 10).

The final complex fracture network example is a $2 \mathrm{~m}$ section of a longer strike-slip fault system with decimeterscale displacements (Figure 11). The fault system comprises NNE-trending right-lateral strike-slip segments that separate a series of ENE-striking centimeter-decimeter-scale pull- 


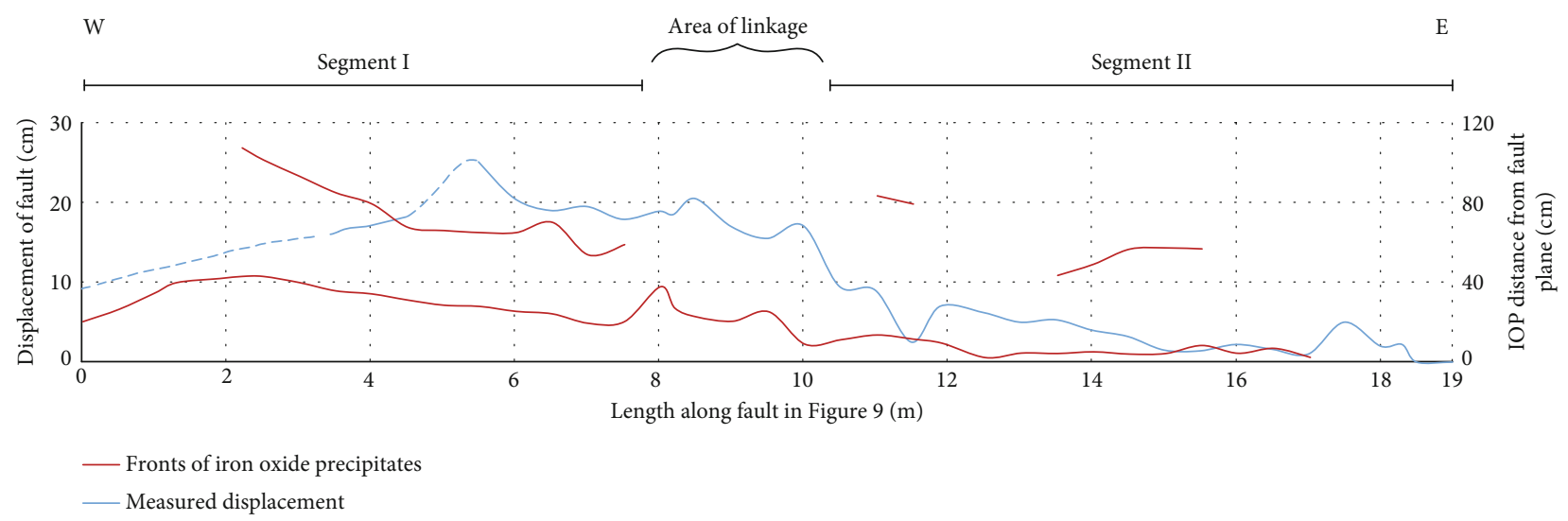

Figure 10: The graph shows the extent of the fronts of iron oxide precipitates (in red) vs. the length of the fault, as well as the lengthdisplacement relationship (in blue) of the studied network in Figure 9. The prominent fronts of iron oxide precipitates exhibit an overall widening from $\mathrm{E}$ to $\mathrm{W}$, tapering towards the $\mathrm{E}$ and terminating along what is segment II in Figure 9. This coincides with the eastward decrease of displacement.

apart structures (see also Figure 3 in the supplementary materials). Branch intensity and connecting node frequency maps in Figures 11(b) and 11(c) show peaks where the main strike-slip faults intersect; however, there is no obvious correlation between IOP distributions. Instead, zones of bleaching/reduction of iron in the limestone can be observed along the pull-apart structures, followed by a zone of higher IOPs (Figure 11(a)), indicating that these pull-apart structures were the main flow conduits along the fault system.

5.5. Hybrid Structural Networks. At Hokianga, New Zealand, we documented a hybrid network where fractures are interacting with highly permeable layers (Figure 12). This hybrid network consists of a fracture network with a conjugate set of fractures trending NNE-SSW and NE-SW, intersecting at an angle of approximately $70^{\circ}$ (Figures $12(\mathrm{a})$ and 12(b)). In this example, the orange-brown colour of the IOPs are not only localized along fractures but also along selected facies/strata in the host sandstone. Contour maps of the connecting node frequency and branch intensity of the fracture network show local highs distributed across the network (Figures 12(c) and 12(d)). When the highly permeable layers are also included, making it a hybrid network, there is an obvious increase in the connecting node frequencies and branch intensities (Figures 12(e) and 12(f)). In this case, the later fracture network appears to provide connections between the highly permeable layers, thus creating a hybrid network of flow conduits.

\section{Discussion}

In the following subchapters, we will first discuss how simple geological heterogeneities affect fluid flow, before moving on to fracture network properties and their spatial variations.

\subsection{How Do Simple Geological Heterogeneities Affect Flow?}

6.1.1. Controls of Depositional Architecture on Fluid Flow. Fluid flow, and therefore also the distribution of IOPs, are sensitive to the inherent pore network variability in the host rocks in which they occur. The depositional architecture of a sediment or sedimentary rock is the end product of depositional processes and following diagenesis, which control the distribution of grain type, size, sorting, cementation, alteration, and therefore also host rock properties and the configuration of the pore space (i.e., porosity and permeability) in a rock. Contrasts in flow properties across bounding surfaces, facies boundaries, bed sets, and individual laminae may be significant and may thus be considered a first-order control on variations in flow behaviour (see e.g., $[90,91])$. For example, Chandler et al. [92] reported permeability contrast spanning 5 orders of magnitude in a $41 \mathrm{~m}$ thick aeolian sandstone succession, and 1-2 magnitude-order permeability contrast between individual crossbeds within a single aeolian dune unit. Fluid flow and iron oxide deposition can hence be spatially controlled by depositional architecture, as illustrated in Figure 3(a) (lower part of image) and Figure 3(b), where IOPs are delineated by crossbeds in sandstone. Depositional architecture as such represents a fundamental control on fluid flow in sedimentary rocks; appreciating the controls of depositional architecture on flow, and the effect of depositional heterogeneities, is a prerequisite that should go hand-inhand with considering structural controls on flow.

6.1.2. Structure Type: Conduit or Barrier? Having briefly discussed the controls of depositional architectural variability, we move on to structural controls on flow and iron oxide deposition. Structures such as faults, other types of fractures, and deformation bands also represent an important control on fluid flow, and whereas joints and unsealed faults may form significant conduits for fluid flow, cataclastic deformation bands, veins, and sealing faults (e.g., faults with shale smear, cataclastic fault rocks, and cementation) may represent effective seals or baffles for flow (e.g., [2, 93, 94]).

Any open or permeable fracture (e.g., an uncemented extension fracture or fault) may transmit fluid flow [95-97]. By localizing fluid flow, fractures may therefore cause iron oxide precipitates to be deposited locally around them (e.g., $[5,39,52,98])$. The examples in Figures 3 and 4 illustrate this 


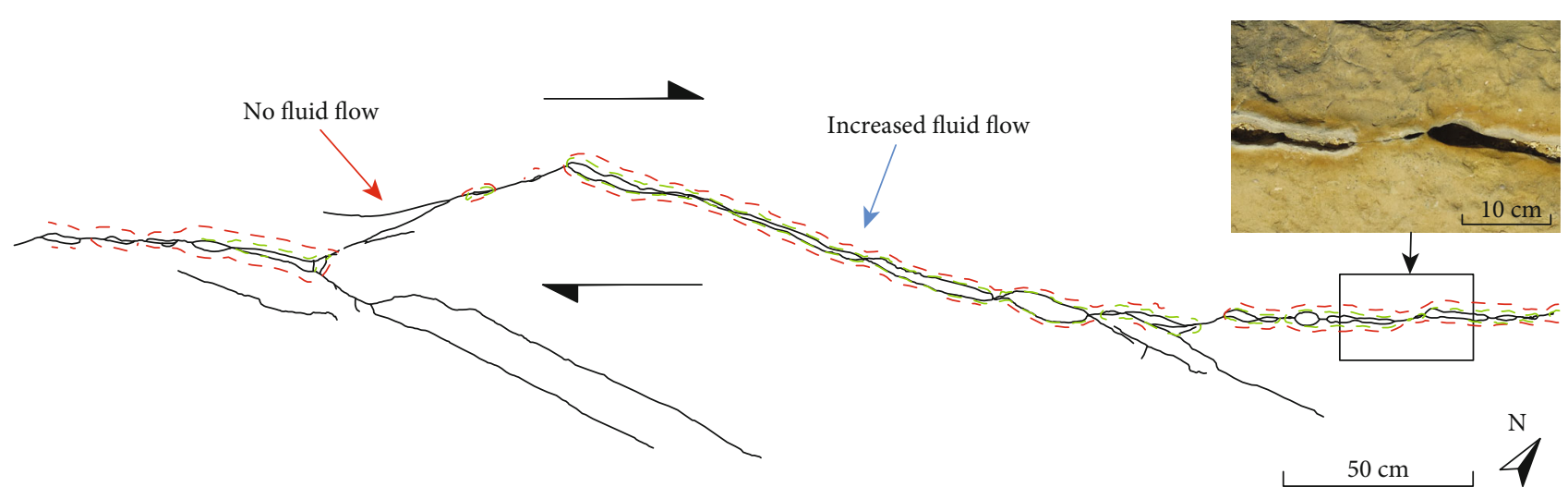

(a) Fracture network

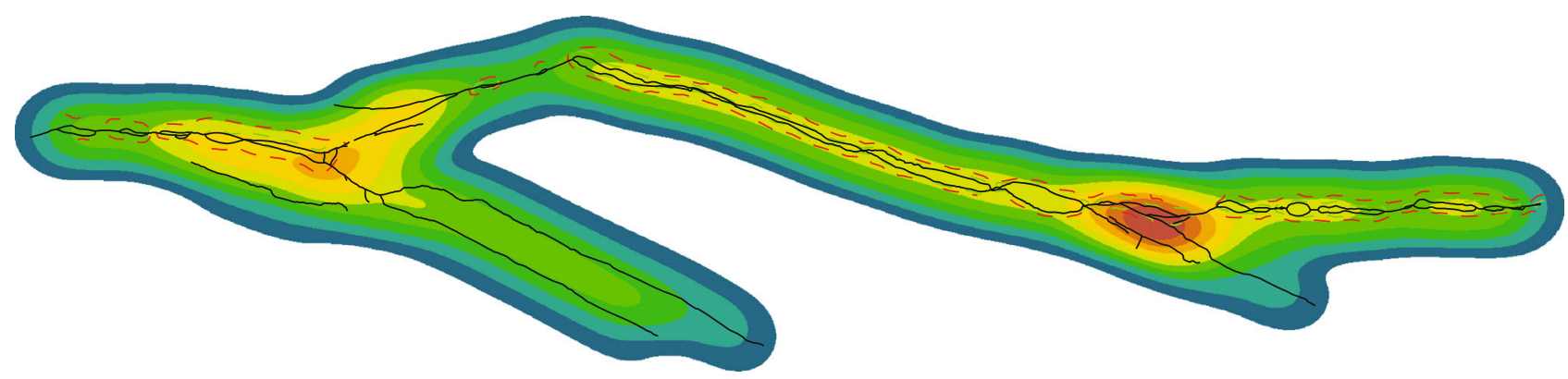

(b) Branch intensity

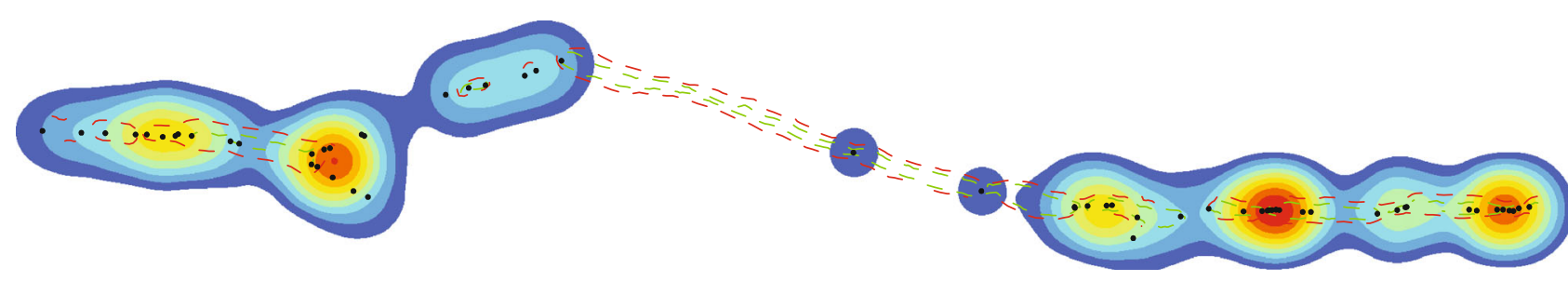

(c) Connecting node frequency

\begin{tabular}{|c|c|}
\hline $\begin{array}{l}\text { Branch intensity } \\
\left(\mathrm{m} / \mathrm{m}^{2}\right)\end{array}$ & $\begin{array}{l}\text { Connecting node } \\
\text { frequency }\left(\mathrm{Nc} / \mathrm{m}^{2}\right)\end{array}$ \\
\hline 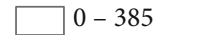 & $0-75$ \\
\hline $385-770$ & $75-151$ \\
\hline $0770-1155$ & $151-226$ \\
\hline $1155-1540$ & $226-301$ \\
\hline $1540-1925$ & $301-377$ \\
\hline $1925-2310$ & $377-452$ \\
\hline $2310-2695$ & $452-527$ \\
\hline $2695-3080$ & $527-603$ \\
\hline $3080-3465$ & $603-678$ \\
\hline $3465-3850$ & $678-753$ \\
\hline
\end{tabular}

-- Front of reduction - Branch
-- Front of IOPs $\quad-\quad$ Connecting node

FIGURE 11: (a) Digitized map of a fracture network at Marsalforn, Malta, with iron oxide precipitates shown as red dashed lines and a front of bleaching shown with a green dashed line. (b) Branch intensity map indicating higher density in complex zones. (c) Connecting node frequency map of the locality. There is no obvious correlation between iron oxide precipitates and higher branch intensity/connecting node frequency in this example; the iron oxide precipitates are rather localized along the pull-apart segments.

nicely. The IOP envelope in Figure 3(a) is highly localized to the joint, as it closely follows its extent and tapers out ahead of the tip. We can hence assume that the joint has served as a fluid flow conduit. The example in Figure 4 is similar, but illustrates the fact that the spatial distribution of iron oxide deposits can be controlled by multiple (two) fractures. Here, 


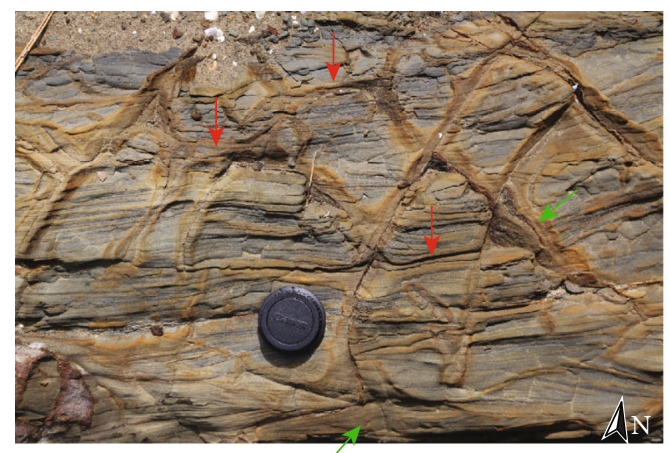

(a) Field photo
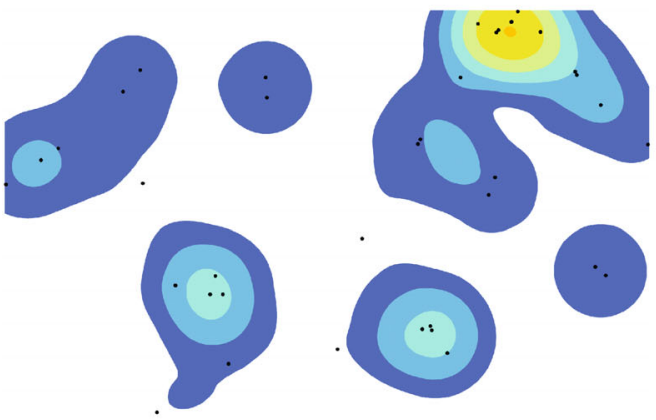

(c) Connecting node frequency

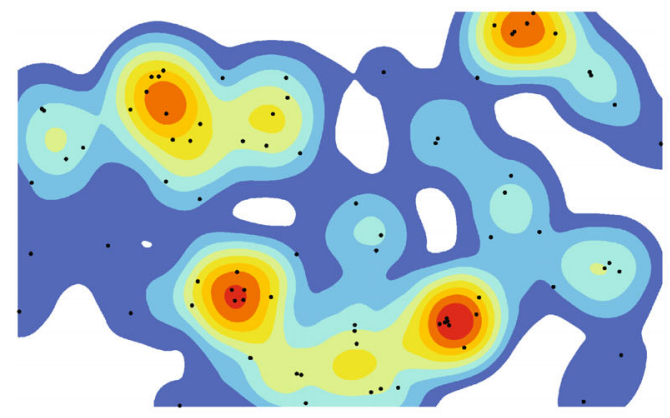

(e) Connecting node frequency, including conductive layers Connecting node
frequency $\left(\mathrm{Nc} / \mathrm{m}^{2}\right)$
\begin{tabular}{|l|l|}
\hline & 0 \\
$0.0169-0.0339$ \\
$0.0338-0.0508$ \\
$0.0507-0.0677$ \\
$0.0677-0.0846$ \\
\hline & $0.0846-0.1016$ \\
\hline $0.1016-0.1185$ \\
$0.1185-0.1354$ \\
$0.1354-0.1523$
\end{tabular}

- Fracture
- Permeable layer
--- Front of iron oxide
deposits

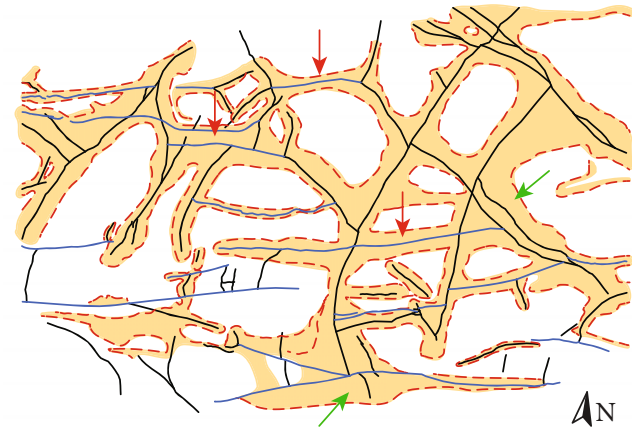

(b) Network of conduits

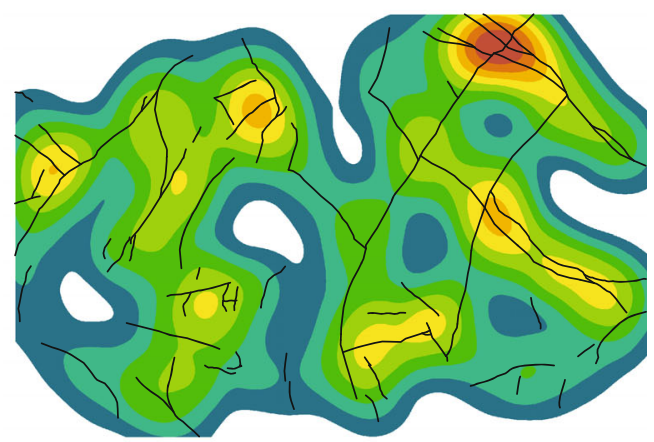

(d) Branch intensity

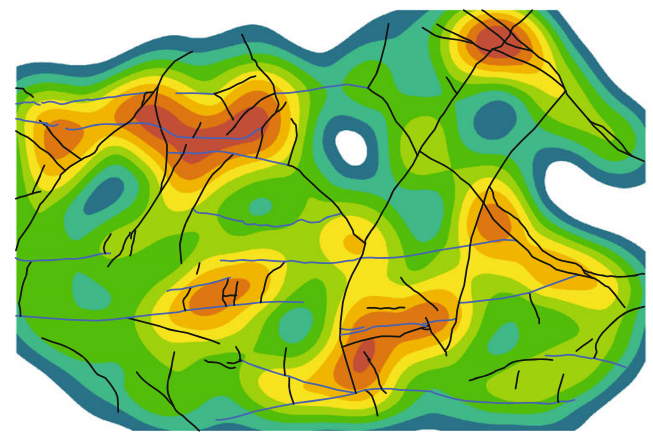

(f) Branch intensity, including conductive layers

Figure 12: (a) Field photo of a simple cross-cutting fracture network from Hokianga, New Zealand, interacting with highly permeable layers in the host rock. (b) A digitized fracture network (black lines) and highly permeable layers (blue lines), surrounded by iron oxide precipitates (orange). Red arrows point to examples of where more permeable layers work as conduits between fractures. (c) Map of the connecting node frequency of the studied part of the fracture network. (d) Map of the branch intensity of the studied part of the fracture network. (e) Map showing the connecting node frequency, including connection points between fractures and highly permeable layers, forming a hybrid network. (f) Branch intensity of the studied network, including the highly permeable layers in the host rock forming a hybrid network. 
the IOP envelope also follows the extent of the joints, but widens where two joints are present, indicating enhanced fluid flow.

As opposed to creating space for enhanced fluid flow, structures may also act as barriers. This is often due to clay smear or juxtaposition of impermeable layers, but also through cementation of fractures or low-permeable deformation bands (e.g., $[20,94,99,100])$. Deformation bands typically have a different effect on flow and iron oxide deposition compared to open fractures, and are capable of baffling and/or redirecting flow (e.g., [101-103]). This is exemplified in Figure 5, where the front of IOPs form a half circle underneath the deformation band cluster. The deformation bands seem to have served as a barrier for fluids, which have ponded against the low-permeable cluster.

However, because of changes in grain size/shape and pore space within deformation bands, capillary properties also change. Despite having a low permeability, some deformation bands can therefore work as capillary conduits in the vadose zone [104, 105]. Iron oxide-bearing fluids may thus saturate relatively low-permeability bands and precipitate localized iron oxide deposits exclusively to the band itself. This is shown in Figures 6(a) and 6(b), where a deformation band highly affected by the IOPs can be seen alongside a second deformation band which in contrast is completely unaffected by the fluids.

Finally, many structures have little or no effect on fluid flow; in such cases, IOPs may be distributed across and irrespective of any structures present. Figures 6(c) and 6(d) exhibit an example of this, where bands of oxidized iron cut right across a deformation band; the deformation band appears to have had no effect on fluid flow, or at least not on the deposition/distribution of IOPs. Deformation bands, fractures, and faults may have little or no effect on flow if the contrast between the flow properties of rocks and structures is low. Additionally, structures that do exhibit a high permeability contrast to host rock may also have a limited practical effect on flow. For example, if the structures are isolated or poorly connected with other low-permeable structures (the fluids will flow around the tips) and the host rock is too highly permeable for any structure to affect flow to any significant degree. In such cases, the effects of structure will be highly dependent on how structures form part of fracture networks, the properties of which may strongly contribute to controlling flow $[13,40]$. This is discussed further in the following section.

\subsection{How Do Fracture Network Properties and Their Spatial Variations Affect Flow?}

6.2.1. Anisotropic Fracture Populations. Although the above examples mainly highlight fractures that either positively localize and conduct flow or clearly prohibit flow, the effect of fractures on flow can be highly variable. As stated earlier, in a population of fractures some fractures may be conductive whereas others may not, or if a population is comprised of two or more fracture sets one set may be conductive while the other sets may not be conductive (e.g., [106]). The latter is exemplified in Figure $7(\mathrm{a})$, where one out of two orthogonal fracture sets in the sandstone is associated with IOPs. Note also that the IOPs in the example (Figure 7(a)) are only localized to parts of the along-strike extent of each fracture in this set. A similar situation can be observed in Figure 7(b), where IOPs are localized along a restricted part of one out of two interacting fracture sets in a limestone bed, showing that this is not restrictive to certain lithologies. The irregular distribution of IOPs may be related to along-strike variability of flow properties of the fractures (cf; [107, 108]), which can be significant over short distances; only parts of the fracture may be conductive at the time of fluid migration, whereas other parts may have too low permeability for fluid transmission.

6.2.2. Geometry and Connectivity in Fracture Networks. The geometry of fractures and fracture networks is another key control on flow in sedimentary rocks (e.g., [36, 40, 109]). The length, orientation, segmentation, and intensity of fractures determine their effect on flow. For example, fracture length and intensity determine the total amount of fractures (length and/or volume of fractures/fractured rock), which translates to the amount of fluid conduits or fluid barriers, present in the rock $[36,110]$. The geometry of fractures affects the dynamics of flow and the localization of fluid-rock interaction, such as seen in the examples presented in Figures 4(a) and 4(b). The length, orientation, and intensity of fractures also determine how they interact in networks, and hence, the geometry controls the connectivity, which is another crucial control on fluid flow in a fracture network as it governs its percolation potential $[36,88]$.

This is highlighted by the example shown in Figure 8, where the widest front of IOPs is located around the intersection point of the two fault segments. The intersection is also characterized by areas of higher branch intensity and connecting node frequency (Figures 8(b) and 8(c)), which confirms this as an area of higher connectivity, hence having the potential to be an area for increased fluid flow. A high concentration of connecting nodes in the southern end of segment I is on the other hand not associated with, or affecting, the IOPs. We propose that this is caused by the lower connectivity (as reflected by the lack of connecting nodes) along the middle part of segment I, or anisotropy along the segment such as potential cementation prohibiting flow along the southernmost part of segment I.

Similar examples have previously been presented in the literature, where fluid flow is directly associated with fault and fracture intersections. Nixon et al. [111] investigated a normal fault relay at Kilve, UK, and illustrated that calcite veins, which represent past conduits, with larger apertures occur at intersections and in areas with high vein intensity (frequency of veins with apertures $>1 \mathrm{~mm}$ per unit length). Dockrill and Shipton [10] present another example where they looked at structural controls on leakage from a natural $\mathrm{CO}_{2}$ storage site along the Little Grand Wash fault and Salt Wash faults in Utah. $\mathrm{CO}_{2}$-charged groundwater precipitates travertine mounds when reaching the surface, and field observations show how these mounds tend to localize at fault intersections. Dockrill and Shipton [10] also use traces of 
iron-oxide reduction as evidence of paleofluid flow in relation to the faults and their associated damage zones. Other precipitates that have served as proof of fluid flow and revealed fault and fracture intersections as conduits are stalactites. Stalactites in carbonate caves indicate high amount of fluid flow in dilational jogs and fracture intersections, where the stalactites are larger than along the rest of the fractures [112].

6.2.3. The Effects of Kinematics and Interaction on Flow. The kinematics of structures are also important. The rates, distribution, timing, and magnitude of slip may control the extent to which faults act as conduits for flow. Greater slip is generally associated with greater deformation and, therefore, also a greater tendency to transmit fluids, such as seen in the example in Figure 9, where the general width distribution of IOP bands around the fracture network appears to correlate with displacement distribution on the main normal fault in the network (Figure 10). The prominent, red-stained IOPs in the footwall exhibit an overall widening from $\mathrm{E}$ to $\mathrm{W}$, tapering towards the $\mathrm{E}$. This general westward widening of the oxidation fronts is matched by a corresponding westward increase in normal displacement. Timing and episodicity of slip are also important; for example, fault reactivation and rejuvenated slip are known to cause reopening of sealed faults (e.g., $[25,32,113])$.

For most fracture and deformation band types, it is generally true that structures affected by a net volume gain (e.g., joints and dilation bands) have a tendency to positively affect flow, whereas structures affected by a net volume loss (e.g., stylolites and compaction bands) may reduce flow properties (e.g., $[19,114,115])$. Structures affected by shear movement may form conduits or barriers to flow depending on the presence of low-permeable fault rocks, any aperture/opening present, or cements. This is highlighted in the example shown in Figure 11, where the distribution and extent of the IOPs show that they are preferentially localized along the opening-dominated pull-apart segments of the fracture network, whereas they are not present around the sheardominated strike-slip segments. This corresponds with previous findings, from both the field and modelling, of fluid flow localizing particularly at fault/fracture jogs or intersections (e.g., $[15,115,116])$.

Furthermore, the relative orientation of fracture sets versus past and present stress fields may also determine their flow properties; fractures that are favourably oriented relative to the axes of maximum principal stress may be kept open (conductive), whereas those unfavourably oriented may be closed (nonconductive) [117]. This can cause some fracture sets in a network to form open conduits, whereas other fracture sets in the same network are nonconductive. This is one possible explanation for the contrasting behaviours of the two fracture sets shown in Figures 7(a) and 7(b). The behaviour may also reflect properties that change through time and space, as some fractures change between being open and closed due to cementation and dissolution/refracturing, and depending on the relative timing of fluid flow, cementation, and deformation at the time fluids are present in the system (e.g., [53, 93, 94]). However, a more complex fault or fracture network, as often found in relay zones of fault linkage zones, would increase the possibility of open fractures as it includes higher fracture intensity with a wider range of fracture orientations making the chance of favourably oriented fractures present higher [40, 107].

6.2.4. Hybrid Networks of Conduits. The different aspects discussed in the previous sections are all independently important controls on fluid flow. However, it is often the interplay between all of the above effects that is key to controlling fluid flow, i.e., the interaction between depositional and structural heterogeneities. This has been treated in previous studies, and may for example affect (i) productionrelated fluid flow in petroleum reservoirs (e.g., [37]), (ii) dolomitization in rift basins [28], and (iii) diagenetic alteration of fault-bound clastic deposits in rift basins (e.g., [25]). However, the interaction between depositional and structural controls on flow can also be considered from a network perspective (sensu [44]), a relationship which is poorly documented in literature, and hence the contribution herein is a novel addition to the research database.

Through Figure 12, we present an example of a hybrid network of structural and depositional conduits, where the IOPs follow both the fractures in the network as well as some layers of the sandstone. This combination of faciesselective and fracture-controlled IOPs portrays a complex network of palaeoconduits. The example shows that a combination of open fractures and high-permeable layers can provide a very well-connected hybrid network of fluid conduits, as demonstrated through the increased branch intensity (compare Figure 12(e) with Figure 12(f)) and connecting node frequency (compare Figure 12(c) with Figure 12(d)), where the fracture network contributes to create a connection between the permeable layers and vice versa. This highlights the interaction between fracturecontrolled conduits and facies-controlled conduits, and illustrates how considering depositional or structural elements in isolation may lead to an incomplete understanding of potential paleofluid conduits (Figures 12(c) and $12(\mathrm{e}))$.

6.3. Implications for Assessing Fluid Flow in the Subsurface. This paper presents a new perspective on structural and stratigraphic controls on fluid flow, incorporating network analysis into an overview on geologic controls on flow in sedimentary rocks. An understanding of fluid flow through geological structures and fracture networks is important for a wide range of reasons. This includes hydrocarbon seal risk assessment, hazard maps for radon gas, prediction of earthquake localization, resource management in connection to groundwater and geothermal energy, and more. For example, Gartrell et al. [93] examined fault intersections as hydrocarbon leakage zones through numerical modelling, and they found that zones of high dilation were generated close to fault intersections, leading to highly permeable zones with a concentration of open fractures ideal for fluid migration. As such, understanding the locations of fluid conduits, which we have listed and presented 


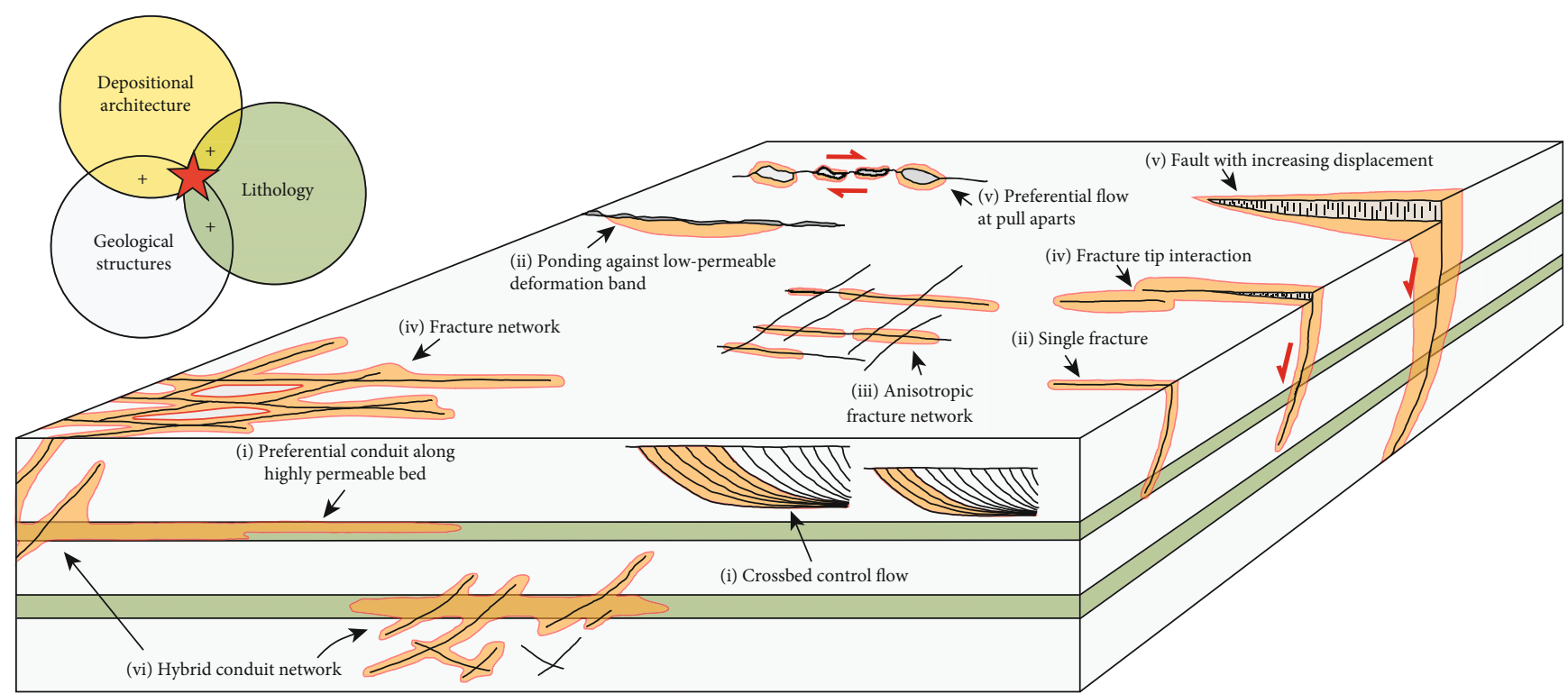

FIGURE 13: Schematic illustration of the examples of controls on fluid flow in sedimentary rocks presented herein, using iron oxide precipitates (orange) as indicator of palaeofluid flow. The fluid flow controls are divided into six groups based upon the main control: (i) host rock properties and depositional architecture, as shown in Figure 3; (ii) geological structures as conduits or barriers, as shown in Figures 4, 5 and 6; (iii) anisotropy in fracture populations, as shown in Figure 7; (iv) geometry and connectivity, as shown in Figure 8; (v) kinematics and interaction, as shown in Figures 9 and 11; (vi) hybrid depositional-structural conduit networks, as shown in Figure 12. All of these controls may also interact with each other, as illustrated in the top left corner.

examples of herein, can be of economic importance in terms of understanding the risk for hydrocarbon leakage or locating economically significant ore deposits $[8,13$, $17,96,118]$.

Understanding the relationship between fluid flow, structures, and depositional architecture in sedimentary rocks also strongly applies to environmental issues, like storage of $\mathrm{CO}_{2}$, radioactive waste disposal contaminant transport, and flow patterns of groundwater $[7,10,16]$. Mechanisms associated with deeper situated (below groundwater table), high-level radioactive waste, e.g., groundwater radiolysis, can form fronts of IOPs around the zones with high-level radioactive waste $[6,16,52]$. This makes fluid flow, and hence IOPs, important for the understanding of radioactive waste migration. Another fluid stored in underground repositories is $\mathrm{CO}_{2}$, which is also highly dependent on conduits or barriers. Shipton et al. [119] examined evidence of $\mathrm{CO}_{2}$ migration along normal faults and found that geysers and hydrocarbon seep were localizing along faults. Their observations are supported by Dockrill and Shipton [10], who investigated the structural control on $\mathrm{CO}_{2}$ leakage from a natural storage site and did field observations of bleaching and mineralization indicating that the paleofluid flow followed the fracture network in the damage zone of the faults. Those results show the importance of knowledge about the structure characteristics to prevent $\mathrm{CO}_{2}$ leakage into the atmosphere.

The understanding and prediction of fluid flow in sedimentary rocks are also highly valuable in subsurface modelling $[7,11,16,82,96,120-122]$. As such, a quantification of fluid flow in relation to fractures, fracture networks, and depositional structures can help to improve our understand- ing and prediction of fluid flow in the subsurface, and is of high value.

\section{Conclusions}

In this paper we have discussed the key structural controls on fluid flow in sedimentary rocks and the relationship between fluid flow, structures, and depositional architecture. In particular, we focused on the role of fracture network properties on flow, and the role of hybrid networks, which is poorly documented. Our study offers an overview of simple, direct observational evidence for the different controls on fluid flow, using iron oxide precipitates (IOPs) as evidence of paleofluid flow patterns. The examples herein are assembled in a schematic illustration in Figure 13. Along with the literature review, these examples allow us to identify some key factors that are instrumental in controlling fluid flow patterns in sedimentary rocks globally:

(1) Depositional architecture and host rock properties represent a first-order control on fluid flow in sedimentary rocks, and flow property contrasts associated with different bounding surfaces, facies, beds, and individual laminae may be sufficient to control and redirect flow

(2) The conduit and/or barrier potential of geological structures such as faults, fractures, and deformation bands are key to their effect on flow; whereas joints and unsealed faults may form significant conduits for fluid flow, cataclastic deformation bands, veins, and sealing faults (e.g., faults with shale smear, 
cataclastic fault rocks, and cementation) may represent effective seals or baffles for flow

(3) Anisotropy in fracture populations, such as where fracture properties vary spatially and/or temporally along single structures or within a network, may cause differential effects on flow

(4) In fracture networks, geometry and connectivity of the fractures forming part of the network are key to understanding flow. The length, orientation, and intensity of fractures determine how individual fractures interact in the network, which in turn controls network connectivity and therefore percolation threshold and flow properties within the network

(5) Kinematics and interaction within a network are other key factors controlling flow. Whereas structures dominated by opening-mode displacement generally have a positive effect on flow, closing-mode displacement generally reduces flow, and structures affected by shear movement may form conduits or barriers depending on the presence of low-permeable fault rocks, existing aperture, or cements

(6) Finally, we have shown that hybrid networks represent a strong control on flow, as structural and stratal conduits can interact to form a well-connected network of conduits

Besides these factors, structural controls on fluid flow are highly dependent on timing, as the properties of both rocks and geological structures may transiently and cyclically vary over time.

\section{Conflicts of Interest}

The authors declare that they have no conflicts of interest.

\section{Acknowledgments}

We acknowledge funding for a personal $\mathrm{PhD}$ grant for Vilde Dimmen from VISTA - a basic research program in collaboration between the Norwegian Academy of Science and Letters and Equinor (grant number 6272). Atle Rotevatn also acknowledges funding for the ANIGMA project from the Norwegian Research Council in the context of the ENERGIX program (grant number 244129/E20), and from Equinor through the Akademia agreement. David Peacock, Kari Nærland, Thomas Berg Kristensen, Eivind Bastesen, and Arild Andresen are thanked for inspiring discussions. Peacock is also thanked for introducing us to the Gozo locality used herein.

\section{Supplementary Materials}

Example 1: (a) overview field photo of example 1, Ras ir Raheb, Malta, with close-up photograph showing a halo of iron oxide precipitates; (b) photomosaic of the fracture network; (c) digitized fracture network of the locality. Example 2: (a) overview field photo of example 2, Ras ir Raheb, Malta; (b) close-up photograph showing the iron oxide pre- cipitate bands in the foot wall along the fault; (c) photomosaic of the fracture network along the fault; (d) digitized fracture network of the locality. Example 3: (a) overview field photo of example 3, Marsalforn, Malta; (b) photomosaic of the fracture network with close-up photograph showing the iron oxide precipitates around pull aparts; (c) digitized fracture network of the locality. (Supplementary Materials)

\section{References}

[1] D. R. Faulkner, C. A. L. Jackson, R. J. Lunn et al., “A review of recent developments concerning the structure, mechanics and fluid flow properties of fault zones," Journal of Structural Geology, vol. 32, no. 11, pp. 1557-1575, 2010.

[2] H. Fossen and A. Bale, "Deformation bands and their influence on fluid flow," AAPG Bulletin, vol. 91, no. 12, pp. 1685-1700, 2007.

[3] W. T. Parry, M. A. Chan, and B. Beitler, "Chemical bleaching indicates episodes of fluid flow in deformation bands in sandstone," AAPG Bulletin, vol. 88, no. 2, pp. 175-191, 2004.

[4] T. Volatili, M. Zambrano, A. Cilona et al., "From fracture analysis to flow simulations in fractured carbonates: the case study of the Roman Valley Quarry (Majella Mountain, Italy)," Marine and Petroleum Geology, vol. 100, pp. 95-110, 2019.

[5] K. Ogata, K. Senger, A. Braathen, and J. Tveranger, "Fracture corridors as seal-bypass systems in siliciclastic reservoir-cap rock successions: field-based insights from the Jurassic Entrada Formation (SE Utah, USA)," Journal of Structural Geology, vol. 66, pp. 162-187, 2014.

[6] H. Yoshida, K. Yamamoto, S. Yogo, and Y. Murakami, "An analogue of matrix diffusion enhanced by biogenic redox reaction in fractured sedimentary rock," Journal of Geochemical Exploration, vol. 90, no. 1-2, pp. 134-142, 2006.

[7] V. F. Bense, T. Gleeson, S. E. Loveless, O. Bour, and J. Scibek, "Fault zone hydrogeology," Earth-Science Reviews, vol. 127, pp. 171-192, 2013.

[8] N. J. Beukes, J. Gutzmer, and J. Mukhopadhyay, "The geology and genesis of high-grade hematite iron ore deposits," Applied Earth Science, vol. 112, no. 1, pp. 18-25, 2013.

[9] J. R. J. Davidson, J. Fairley, A. Nicol, D. Gravley, and U. Ring, "The origin of radon anomalies along normal faults in an active rift and geothermal area," Geosphere, vol. 12, no. 5, pp. 1656-1669, 2016.

[10] B. Dockrill and Z. K. Shipton, "Structural controls on leakage from a natural $\mathrm{CO}_{2}$ geologic storage site: Central Utah, USA," Journal of Structural Geology, vol. 32, no. 11, pp. 1768-1782, 2010.

[11] K. Katsanou, K. Stratikopoulos, E. Zagana, and N. Lambrakis, "Radon changes along main faults in the broader Aigion region, NW Peloponnese," Bulletin of the Geological Society of Greece, vol. 43, pp. 1726-1736, 2017.

[12] J. D. Muirhead, G. Airoldi, J. V. Rowland, and J. D. L. White, "Interconnected sills and inclined sheet intrusions control shallow magma transport in the Ferrar Large Igneous Province, Antarctica," Geological Society of America Bulletin, vol. 124, no. 1-2, pp. 162-180, 2012.

[13] A. Rotevatn and H. Fossen, "Simulating the effect of subseismic fault tails and process zones in a siliciclastic reservoir analogue: implications for aquifer support and trap 
definition," Marine and Petroleum Geology, vol. 28, no. 9, pp. 1648-1662, 2011.

[14] J. V. Rowland and R. H. Sibson, "Structural controls on hydrothermal flow in a segmented rift system, Taupo Volcanic Zone, New Zealand," Geofluids, vol. 4, no. 4, 283 pages, 2004.

[15] D. J. Sanderson and X. Zhang, "Critical stress localization of flow associated with deformation of well-fractured rock masses, with implications for mineral deposits," Geological Society, London, Special Publications, vol. 155, no. 1, pp. 6981, 1999.

[16] H. Yoshida, R. Metcalfe, K. Yamamoto et al., "Redox front formation in an uplifting sedimentary rock sequence: an analogue for redox-controlling processes in the geosphere around deep geological repositories for radioactive waste," Applied Geochemistry, vol. 23, no. 8, pp. 2364-2381, 2008.

[17] Y. Zhang, B. E. Hobbs, A. Ord et al., "The influence of faulting on host-rock permeability, fluid flow and ore genesis of gold deposits: a theoretical 2D numerical model," Journal of Geochemical Exploration, vol. 78-79, pp. 279-284, 2003.

[18] N. C. Davatzes, P. Eichhubl, and A. Aydin, "Structural evolution of fault zones in sandstone by multiple deformation mechanisms: Moab fault, southeast Utah,” GSA Bulletin, vol. 117, no. 1, pp. 135-148, 2005.

[19] H. Fossen, R. A. Schultz, Z. K. Shipton, and K. Mair, "Deformation bands in sandstone: a review," Journal of the Geological Society, vol. 164, no. 4, pp. 755-769, 2007.

[20] Y. Missenard, A. Bertrand, P. Vergely, A. Benedicto, M. E. Cushing, and M. Rocher, "Fracture-fluid relationships: implications for the sealing capacity of clay layers-insights from field study of the Blue Clay formation, Maltese islands," Bulletin de la Societe Geologique de France, vol. 185, no. 1, pp. 51-63, 2014.

[21] F. Agosta and D. L. Kirschner, "Fluid conduits in carbonatehosted seismogenic normal faults of central Italy," Journal of Geophysical Research: Solid Earth, vol. 108, no. B4, 2003.

[22] E. Bastesen and A. Rotevatn, "Evolution and structural style of relay zones in layered limestone-shale sequences: insights from the Hammam Faraun Fault Block, Suez Rift, Egypt," Journal of the Geological Society, vol. 169, no. 4, pp. 477-488, 2012.

[23] A. Billi, F. Salvini, and F. Storti, "The damage zone-fault core transition in carbonate rocks: implications for fault growth, structure and permeability," Journal of Structural Geology, vol. 25, no. 11, pp. 1779-1794, 2003.

[24] N. J. C. Farrell, D. Healy, and C. W. Taylor, "Anisotropy of permeability in faulted porous sandstones," Journal of Structural Geology, vol. 63, pp. 50-67, 2014.

[25] T. B. Kristensen, A. Rotevatn, D. C. P. Peacock, G. A. Henstra, I. Midtkandal, and S. A. Grundvag, "Structure and flow properties of syn-rift border faults: the interplay between fault damage and fault-related chemical alteration (Dombjerg Fault, Wollaston Forland, NE Greenland)," Journal of Structural Geology, vol. 92, pp. 99-115, 2016.

[26] J. Hirani, E. Bastesen, A. Boyce et al., "Controls on the formation of stratabound dolostone bodies, Hammam Faraun Fault block, Gulf of Suez," Sedimentology, vol. 65, no. 6, pp. 19732002, 2018

[27] M. Holland and J. L. Urai, "Evolution of anastomosing crackseal vein networks in limestones: insight from an exhumed high-pressure cell, Jabal Shams, Oman Mountains," Journal of Structural Geology, vol. 32, no. 9, pp. 1279-1290, 2010.
[28] C. Hollis, E. Bastesen, A. Boyce et al., "Fault-controlled dolomitization in a rift basin," Geology, vol. 45, no. 3, pp. 219-222, 2017.

[29] S. E. Laubach, J. E. Olson, and J. F. W. Gale, "Are open fractures necessarily aligned with maximum horizontal stress?," Earth and Planetary Science Letters, vol. 222, no. 1, pp. 191195, 2004.

[30] J. G. Ramsay, "The crack-seal mechanism of rock deformation," Nature, vol. 284, no. 5752, pp. 135-139, 1980.

[31] V. F. Bense and M. A. Person, "Faults as conduit-barrier systems to fluid flow in siliciclastic sedimentary aquifers," Water Resources Research, vol. 42, no. 5, 2006.

[32] D. Wiprut and M. D. Zoback, "Fault reactivation and fluid flow along a previously dormant normal fault in the northern North Sea," Geology, vol. 28, no. 7, pp. 595-598, 2000.

[33] E. Bonnet, O. Bour, N. E. Odling et al., "Scaling of fracture systems in geological media," Reviews of Geophysics, vol. 39, no. 3, pp. 347-383, 2001.

[34] A. Gudmundsson, S. S. Berg, K. B. Lyslo, and E. Skurtveit, "Fracture networks and fluid transport in active fault zones," Journal of Structural Geology, vol. 23, no. 2-3, pp. 343-353, 2001.

[35] D. J. Sanderson, D. C. P. Peacock, C. W. Nixon, and A. Rotevatn, "Graph theory and the analysis of fracture networks," Journal of Structural Geology, vol. 125, pp. 155-165, 2019.

[36] D. J. Sanderson and C. W. Nixon, "Topology, connectivity and percolation in fracture networks," Journal of Structural Geology, vol. 115, pp. 167-177, 2018.

[37] A. Rotevatn, S. J. Buckley, J. A. Howell, and H. Fossen, "Overlapping faults and their effect on fluid flow in different reservoir types: a LIDAR-based outcrop modeling and flow simulation study," AAPG Bulletin, vol. 93, no. 3, pp. 407427, 2009.

[38] P. S. Ringrose, K. S. Sorbie, P. W. M. Corbett, and J. L. Jensen, "Immiscible flow behaviour in laminated and cross-bedded sandstones," Journal of Petroleum Science and Engineering, vol. 9, no. 2, pp. 103-124, 1993.

[39] F. Balsamo, F. H. R. Bezerra, M. M. Vieira, and F. Storti, "Structural control on the formation of iron-oxide concretions and Liesegang bands in faulted, poorly lithified Cenozoic sandstones of the Paraiba Basin, Brazil," Geological Society of America Bulletin, vol. 125, no. 5-6, pp. 913-931, 2013.

[40] V. Dimmen, A. Rotevatn, D. C. P. Peacock, C. W. Nixon, and K. Nærland, "Quantifying structural controls on fluid flow: insights from carbonate-hosted fault damage zones on the Maltese Islands," Journal of Structural Geology, vol. 101, pp. 43-57, 2017.

[41] O. B. Duffy, C. W. Nixon, R. E. Bell et al., "The topology of evolving rift fault networks: single-phase vs multi-phase rifts," Journal of Structural Geology, vol. 96, pp. 192-202, 2017.

[42] T. Manzocchi, "The connectivity of two-dimensional networks of spatially correlated fractures," Water Resources Research, vol. 38, no. 9, pp. 1-20, 2002.

[43] C. K. Morley and C. W. Nixon, "Topological characteristics of simple and complex normal fault networks," Journal of Structural Geology, vol. 84, pp. 68-84, 2016.

[44] D. J. Sanderson and C. W. Nixon, "The use of topology in fracture network characterization," Journal of Structural Geology, vol. 72, pp. 55-66, 2015. 
[45] D. C. P. Peacock, C. W. Nixon, A. Rotevatn, D. J. Sanderson, and L. F. Zuluaga, "Glossary of fault and other fracture networks," Journal of Structural Geology, vol. 92, pp. 12-29, 2016.

[46] M. A. Antonellini, A. Aydin, and D. D. Pollard, "Microstructure of deformation bands in porous sandstones at Arches National Park, Utah," Journal of Structural Geology, vol. 16, no. 7, pp. 941-959, 1994.

[47] G. Ballas, R. Soliva, J.-P. Sizun, A. Benedicto, T. Cavailhes, and S. Raynaud, "The importance of the degree of cataclasis in shear bands for fluid flow in porous sandstone, Provence, France," AAPG Bulletin, vol. 96, no. 11, pp. 2167-2186, 2012.

[48] A. Rotevatn, H. S. Fossmark, E. Bastesen, E. Thorsheim, and A. Torabi, "Do deformation bands matter for flow? Insights from permeability measurements and flow simulations in porous carbonate rocks," Petroleum Geoscience, vol. 23, no. 1, pp. 104-119, 2017.

[49] A. Rotevatn, A. Torabi, H. Fossen, and A. Braathen, "Slipped deformation bands: a new type of cataclastic deformation bands in Western Sinai, Suez Rift, Egypt," Journal of Structural Geology, vol. 30, no. 11, pp. 1317-1331, 2008.

[50] K. R. Sternlof, J. R. Chapin, D. D. Pollard, and L. J. Durlofsky, "Permeability effects of deformation band arrays in sandstone," AAPG Bulletin, vol. 88, no. 9, pp. 1315-1329, 2004.

[51] W. L. Taylor and D. D. Pollard, "Estimation of in situ permeability of deformation bands in porous sandstone, Valley of Fire, Nevada," Water Resources Research, vol. 36, no. 9, pp. 2595-2606, 2000.

[52] F. Akagawa, H. Yoshida, S. Yogo, and K. Yamomoto, "Redox front formation in fractured crystalline rock: an analogue of matrix diffusion in an oxidizing front along waterconducting fractures," Geochemistry-Exploration Environment Analysis, vol. 6, no. 1, pp. 49-56, 2006.

[53] P. Eichhubl, N. C. Davatzes, and S. P. Becker, "Structural and diagenetic control of fluid migration and cementation along the Moab fault, Utah," AAPG Bulletin, vol. 93, no. 5, pp. 653-681, 2009.

[54] L. Fu, K. L. Milliken, and J. M. Sharp Jr., "Porosity and permeability variations in fractured and Liesegang-banded Breathitt sandstones (Middle Pennsylvanian), eastern Kentucky: diagenetic controls and implications for modeling dual-porosity systems," Journal of Hydrology, vol. 154, no. 1-4, pp. 351-381, 1994.

[55] P. Ortoleva, G. Auchmuty, J. Chadam et al., "Redox front propagation and banding modalities," Physica D: Nonlinear Phenomena, vol. 19, no. 3, pp. 334-354, 1986.

[56] P. M. Barnes and B. M. de Lépinay, "Rates and mechanics of rapid frontal accretion along the very obliquely convergent southern Hikurangi margin, New Zealand," Journal of Geophysical Research: Solid Earth, vol. 102, no. B11, pp. 2493124952, 1997.

[57] R. J. Norris, P. O. Koons, and A. F. Cooper, "The obliquelyconvergent plate boundary in the South Island of New Zealand: implications for ancient collision zones," Journal of Structural Geology, vol. 12, no. 5-6, pp. 715-725, 1990.

[58] G. H. Browne and R. M. Slatt, "Outcrop and behind-outcrop characterization of a late Miocene slope fan system, Mt. Messenger Formation, New Zealand," AAPG Bulletin, vol. 86, pp. 841-862, 2002.

[59] P. R. King, G. H. Browne, R. M. Slatt, and P. Weimer, "Sequence architecture of exposed late Miocene basin floor fan and channel-levee complexes (Mount Messenger Formation), Taranaki Basin, New Zealand," in Submarine Fans and Turbidite Systems: Sequence Stratigraphy, Reservoir Architecture and Production Characteristics; Gulf of Mexico and International: Proceedings Gulf Coast Section Society of Economic Paleontologists and Mineralogists Foundation Fifteenth Annual Research Conference, GCS017, pp. 177-192, Houston, TX, USA, December 1994.

[60] S. D. Nodder, C. S. Nelson, and P. J. J. Kamp, "Massemplaced siliciclastic-volcaniclastic-carbonate sediments in Middle Miocene shelf-to-slope environments at Waikawau, northern Taranaki, and some implications for Taranaki Basin development," New Zealand Journal of Geology and Geophysics, vol. 33, no. 4, pp. 599-615, 1990.

[61] M. G. Laird and J. D. Bradshaw, "The break-up of a long-term relationship: the Cretaceous separation of New Zealand from Gondwana," Gondwana Research, vol. 7, no. 1, pp. 273-286, 2004.

[62] R. Sutherland, P. King, and R. Wood, "Tectonic evolution of Cretaceous rift basins in south-eastern Australia and New Zealand: implications for exploration risk assessment," in Eastern Australasian Basins Symposium, a Refocussed Energy Perspective for the Future, K. Hill and T. Bernecker, Eds., pp. 3-14, Petroleum Exploration Society of Australia, Special Publication, 2001.

[63] M. Giba, J. J. Walsh, and A. Nicol, "Segmentation and growth of an obliquely reactivated normal fault," Journal of Structural Geology, vol. 39, pp. 253-267, 2012.

[64] C. Childs, J. J. Walsh, T. Manzocchi et al., "Definition of a fault permeability predictor from outcrop studies of a faulted turbidite sequence, Taranaki, New Zealand," Geological Society, London, Special Publications, vol. 292, no. 1, pp. 235-258, 2007.

[65] A. Nicol, C. Childs, J. J. Walsh, and K. W. Schafer, "A geometric model for the formation of deformation band clusters," Journal of Structural Geology, vol. 55, pp. 21-33, 2013.

[66] C. J. Adams, N. Mortimer, H. J. Campbell, and W. L. Griffin, "Detrital zircon geochronology and sandstone provenance of basement Waipapa terrane (Triassic-Cretaceous) and Cretaceous cover rocks (Northland allochthon and Houhora complex) in northern North Island, New Zealand," Geological Magazine, vol. 150, no. 1, pp. 89-109, 2013.

[67] R. B. Evans, "Tertiary tectonic development of Whangaroa district, northeastern Northland, New Zealand," New Zealand Journal of Geology and Geophysics, vol. 35, no. 4, pp. 549-559, 1992.

[68] R. F. Hay, "The geology of Mangakahia Subdivision," in New Zealand Department of Scientific and Industrial Research, vol. 61, pp. 1-109, New Zealand Geological Survey Bulletine, 1960.

[69] P. F. Ballance and K. B. Spörli, "Northland allochthon," Journal of the Royal Society of New Zealand, vol. 9, no. 2, pp. 259$275,1979$.

[70] M. J. Isaac, Geology of the Kaitaia area: scale 1:250 000, Institute of Geological and Nuclear Sciences, Geological map +41 folded map, Lower Hutt, 1996.

[71] R. B. Evans, "Profile of a piggyback basin: early Miocene Otaua Group and Waipoua Subgroup, western Northland, New Zealand," New Zealand Journal of Geology and Geophysics, vol. 37, no. 1, pp. 87-99, 1994. 
[72] C. -D. Reuther and G. H. Eisbacher, "Pantelleria Rift-crustal extension in a convergent intraplate setting," Geologische Rundschau, vol. 74, no. 3, pp. 585-597, 1985.

[73] W. Cavazza and F. C. Wezel, "The Mediterranean region-a geological primer," Episodes, vol. 26, no. 3, pp. 160-168, 2003.

[74] C. J. Dart, D. W. J. Bosence, and K. R. Mcclay, "Stratigraphy and structure of the Maltese Graben System," Journal of the Geological Society, vol. 150, no. 6, pp. 1153-1166, 1993.

[75] K. C. Hill and A. B. Hayward, "Structural constraints on the Tertiary plate tectonic evolution of Italy," Marine and Petroleum Geology, vol. 5, no. 1, pp. 2-16, 1988.

[76] L. Jolivet and C. Faccenna, "Mediterranean extension and the Africa-Eurasia collision,” Tectonics, vol. 19, no. 6, pp. 10951106,2000

[77] C. G. Bonson, C. Childs, J. J. Walsh, M. P. J. Schöpfer, and V. Carboni, "Geometric and kinematic controls on the internal structure of a large normal fault in massive limestones: the Maghlaq Fault, Malta," Journal of Structural Geology, vol. 29, no. 2, pp. 336-354, 2007.

[78] M. W. Putz-Perrier and D. J. Sanderson, "Distribution of faults and extensional strain in fractured carbonates of the North Malta Graben," AAPG Bulletin, vol. 94, no. 4, pp. 435-456, 2010.

[79] E. A. H. Michie, T. J. Haines, D. Healy, J. E. Neilson, N. E. Timms, and C. A. J. Wibberley, "Influence of carbonate facies on fault zone architecture," Journal of Structural Geology, vol. 65, pp. 82-99, 2014.

[80] H. M. Pedley, M. R. House, and B. Waugh, "The geology of Malta and Gozo," Proceedings of the Geologists' Association, vol. 87, no. 3, pp. 325-341, 1976.

[81] T. J. Haines, E. A. H. Michie, J. E. Neilson, and D. Healy, "Permeability evolution across carbonate hosted normal fault zones," Marine and Petroleum Geology, vol. 72, pp. 62-82, 2016.

[82] Y. S. Kim, D. C. P. Peacock, and D. J. Sanderson, "Mesoscale strike-slip faults and damage zones at Marsalforn, Gozo Island, Malta," Journal of Structural Geology, vol. 25, no. 5, pp. 793-812, 2003.

[83] S. S. Berg and T. Skar, "Controls on damage zone asymmetry of a normal fault zone: outcrop analyses of a segment of the Moab fault, SE Utah," Journal of Structural Geology, vol. 27, no. 10, pp. 1803-1822, 2005.

[84] K. A. Foxford, J. J. Walsh, J. Watterson, I. R. Garden, S. C. Guscott, and S. D. Burley, "Structure and content of the Moab Fault Zone, Utah, USA, and its implications for fault seal prediction," Geological Society, London, Special Publications, vol. 147, no. 1, pp. 87-103, 1998.

[85] K. Foxford, I. Garden, S. Guscott et al., "The field geology of the Moab fault," in Geology and Resources of the Paradox Basin, A. C. Huuffman Jr., W. R. Lund, and L. H. Godwin, Eds., vol. 25, pp. 265-283, Utah Geological Association Guidebook, 1996.

[86] B. D. Trudgill, "Evolution of salt structures in the northern Paradox Basin: controls on evaporite deposition, salt wall growth and supra-salt stratigraphic architecture," Basin Research, vol. 23, no. 2, pp. 208-238, 2011.

[87] M. Crabaugh and G. Kocurek, "Entrada Sandstone: an example of a wet aeolian system," Geological Society, London, Special Publications, vol. 72, no. 1, pp. 103-126, 1993.

[88] B. Nyberg, C. W. Nixon, and D. J. Sanderson, "NetworkGT: a GIS tool for geometric and topological analysis of two- dimensional fracture networks," Geosphere, vol. 14, no. 4, pp. 1618-1634, 2018.

[89] L. Jing and O. Stephansson, "Network topology and homogenization of fractured rocks," in Fluid Flow and Transport in Rocks, B. Jamtveit and B. W. D. Yardley, Eds., pp. 191-202, Springer, 1997.

[90] A. Hurst and K. J. Rosvoll, Permeability variations in sandstones and their relationship to sedimentary structures, Reservoir Characterization II, Elsevier, 1991.

[91] M. D. Jackson and A. H. Muggeridge, "Effect of discontinuous shales on reservoir performance during horizontal waterflooding," SPE Journal, vol. 5, no. 4, pp. 446-455, 2013.

[92] M. A. Chandler, G. Kocurek, D. J. Goggin, and L. W. Lake, "Effects of stratigraphic heterogeneity on permeability in eolian sandstone sequence, Page Sandstone, northern Arizona," AAPG Bulletin, vol. 73, pp. 658-668, 1989.

[93] A. Gartrell, Y. Zhang, M. Lisk, and D. Dewhurst, "Fault intersections as critical hydrocarbon leakage zones: integrated field study and numerical modelling of an example from the Timor Sea, Australia," Marine and Petroleum Geology, vol. 21, no. 9, pp. 1165-1179, 2004.

[94] S. J. Jolley, D. Barr, J. J. Walsh, and R. J. Knipe, "Structurally complex reservoirs: an introduction," Geological Society, London, Special Publications, vol. 292, no. 1, pp. 1-24, 2007.

[95] C. A. Barton, M. D. Zoback, and D. Moos, "Fluid flow along potentially active faults in crystalline rock," Geology, vol. 23, no. 8, pp. 683-686, 1995.

[96] R. H. Sibson, "Structural permeability of fluid-driven faultfracture meshes," Journal of Structural Geology, vol. 18, no. 8, pp. 1031-1042, 1996.

[97] R. W. Zimmerman, A. Al-Yaarubi, C. C. Pain, and C. A. Grattoni, "Non-linear regimes of fluid flow in rock fractures," International Journal of Rock Mechanics and Mining Sciences, vol. 41, no. 3, pp. 384-384, 2004.

[98] P. Eichhubl, W. L. Taylor, D. D. Pollard, and A. Aydin, "Paleo-fluid flow and deformation in the Aztec Sandstone at the Valley of Fire, Nevada-evidence for the coupling of hydrogeologic, diagenetic, and tectonic processes," GSA Bulletin, vol. 116, no. 9, pp. 1120-1136, 2004.

[99] Z. K. Shipton, J. P. Evans, and L. B. Thompson, "The geometry and thickness of deformation-band fault core and its influence on sealing characteristics of deformation-band fault zones," AAPG Memoir, vol. 85, pp. 181-195, 2005.

[100] G. Verhaert, P. Muchez, E. Keppens, and M. Sintubin, "Fluid impact and spatial and temporal evolution of normal faulting in limestones. A case study in the Burdur-Isparta Region (SW Turkey)," Geologica Belgica, vol. 12, pp. 59-73, 2009.

[101] S. K. Matthäi, A. Aydin, D. D. Pollard, and S. G. Roberts, "Numerical simulation of departures from radial drawdown in a faulted sandstone reservoir with joints and deformation bands," Geological Society, London, Special Publications, vol. 147, no. 1, pp. 157-191, 1998.

[102] A. Rotevatn, J. Tveranger, J. A. Howell, and H. Fossen, "Dynamic investigation of the effect of a relay ramp on simulated fluid flow: geocellular modelling of the Delicate Arch Ramp, Utah," Petroleum Geoscience, vol. 15, no. 1, pp. 4558, 2009.

[103] L. F. Zuluaga, H. Fossen, and A. Rotevatn, "Progressive evolution of deformation band populations during Laramide fault-propagation folding: Navajo Sandstone, San Rafael 
monocline, Utah, USA," Journal of Structural Geology, vol. 68, pp. 66-81, 2014.

[104] T. Cavailhes, R. Soliva, A. Benedicto, D. Loggia, R. A. Schultz, and C. A. J. Wibberley, "Are cataclastic shear bands fluid barriers or capillarity conduits? Insight from the analysis of redox fronts in porous," in 2nd EAGE International Conference on Fault and Top Seals-From Pore to Basin Scale 2009, Montpellier, France, September 2009.

[105] J. M. Sigda and J. L. Wilson, "Are faults preferential flow paths through semiarid and arid vadose zones?," Water Resources Research, vol. 39, no. 8, p. 1225, 2003.

[106] S. E. Laubach, "Practical approaches to identifying sealed and open fractures," AAPG Bulletin, vol. 87, no. 4, pp. 561-579, 2003.

[107] A. Rotevatn and E. Bastesen, "Fault linkage and damage zone architecture in tight carbonate rocks in the Suez Rift (Egypt): implications for permeability structure along segmented normal faults," in Advances in the Study of Fractured Reservoirs, G. H. Spence, J. Redfern, R. Aguilera, T. G. Bevan, J. W. Cosgrove, G. D. Couples, and J.-M. Daniel, Eds., pp. 79-95, Geological Society, Special Publications, London, 2014.

[108] A. Torabi and H. Fossen, "Spatial variation of microstructure and petrophysical properties along deformation bands in reservoir sandstones," AAPG Bulletin, vol. 93, no. 7, pp. 919938, 2009.

[109] M. Antonellini and A. Aydin, "Effect of faulting on fluid flow in porous sandstones: geometry and spatial distribution," AAPG Bulletin, vol. 79, pp. 642-671, 1995.

[110] C. Zeeb, E. Gomez-Rivas, P. D. Bons, and P. Blum, "Evaluation of sampling methods for fracture network characterization using outcrops," AAPG Bulletin, vol. 97, no. 9, pp. 1545-1566, 2013.

[111] C. W. Nixon, S. Vaagan, D. J. Sanderson, and R. L. Gawthorpe, "Spatial distribution of damage and strain within a normal fault relay at Kilve, UK," Journal of Structural Geology, vol. 118, pp. 194-209, 2019.

[112] Y.-S. Kim and D. J. Sanderson, "Inferred fluid flow through fault damage zones based on the observation of stalactites in carbonate caves," Journal of Structural Geology, vol. 32, no. 9, pp. 1305-1316, 2010.

[113] I. Moeck, G. Kwiatek, and G. Zimmermann, "Slip tendency analysis, fault reactivation potential and induced seismicity in a deep geothermal reservoir," Journal of Structural Geology, vol. 31, no. 10, pp. 1174-1182, 2009.

[114] L. J. Pyrak-Nolte and J. P. Morris, "Single fractures under normal stress: the relation between fracture specific stiffness and fluid flow," International Journal of Rock Mechanics and Mining Sciences, vol. 37, no. 1-2, pp. 245-262, 2000.

[115] X. Zhang, D. J. Sanderson, and A. J. Barker, "Numerical study of fluid flow of deforming fractured rocks using dual permeability model," Geophysical Journal International, vol. 151, no. 2, pp. 452-468, 2002.

[116] N. H. S. Oliver and P. D. Bons, "Mechanisms of fluid flow and fluid-rock interaction in fossil metamorphic hydrothermal systems inferred from vein-wallrock patterns, geometry and microstructure," Geofluids, vol. 1, no. 2, 162 pages, 2001.

[117] T. Tamagawa and D. D. Pollard, "Fracture permeability created by perturbed stress fields around active faults in a fractured basement reservoir," AAPG Bulletin, vol. 92, no. 6, pp. 743-764, 2008.
[118] W. H. Newhouse, Ore Deposits as Related to Structural Features, Princeton University Press, Princeton, New Jersey, 1942.

[119] Z. K. Shipton, J. P. Evans, D. Kirschner, P. T. Kolesar, A. P. Williams, and J. Heath, "Analysis of $\mathrm{CO}_{2}$ leakage through "low-permeability" faults from natural reservoirs in the Colorado Plateau, east-central Utah," in Geological Storage of Carbon Dioxide, S. J. Baines and R. H. Worden, Eds., pp. 43-58, Geological Society, Special Publications, London, 2004.

[120] A. Aydin, "Fractures, faults, and hydrocarbon entrapment, migration and flow," Marine and Petroleum Geology, vol. 17, no. 7, pp. 797-814, 2000.

[121] S. D. Harris, E. McAllister, R. J. Knipe, and N. E. Odling, "Predicting the three-dimensional population characteristics of fault zones: a study using stochastic models," Journal of Structural Geology, vol. 25, no. 8, pp. 1281-1299, 2003.

[122] C.-Y. King, "Gas geochemistry applied to earthquake prediction: an overview," Journal of Geophysical Research: Solid Earth, vol. 91, no. B12, pp. 12269-12281, 1986. 